\title{
Sustainability, Productivity, Profitability and Soil Health With Conservation Agriculture-Based Sustainable Intensification of Oilseed Brassica Production System
}

\section{R.S. Jat}

ICAR-Directorate of Rapeseed-Mustard Research, Bharatpur, Rajasthan (India)

R.L. Choudhary ( $\nabla$ rl.choudhary@icar.gov.in )

ICAR-Directorate of Rapeseed-Mustard Research, Bharatpur, Rajasthan (India)

H.V. Singh

ICAR-Directorate of Rapeseed-Mustard Research, Bharatpur, Rajasthan (India)

M.K. Meena

ICAR-Directorate of Rapeseed-Mustard Research, Bharatpur, Rajasthan (India)

\section{V.V. Singh}

ICAR-Directorate of Rapeseed-Mustard Research, Bharatpur, Rajasthan (India)

P.K. Rai

ICAR-Directorate of Rapeseed-Mustard Research, Bharatpur, Rajasthan (India)

\section{Research Article}

Keywords: Conservation Agriculture (CA), Oilseed brassica (Indian mustard, Brassica juncea L.), Maizemustard (Mz-M)

Posted Date: January 4th, 2021

DOI: https://doi.org/10.21203/rs.3.rs-134034/v1

License: (9) This work is licensed under a Creative Commons Attribution 4.0 International License. Read Full License 


\title{
Sustainability, productivity, profitability and soil health with conservation agriculture based sustainable intensification of oilseed brassica production system
}

R.S. Jat, R.L. Choudhary*, H.V. Singh, M.K. Meena, V.V. Singh \& P.K. Rai

ICAR-Directorate of Rapeseed-Mustard Research, Bharatpur, Rajasthan (India)

\begin{abstract}
Conservation Agriculture (CA) practices getting space world-wide to answer many emerging challenges like; declining factor productivity, deteriorating soil health, water scarcity, climate change, and farm profitability and sustainability. Oilseed brassica (Indian mustard, Brassica juncea L.), a winter oilseed grown under rainfed agro-ecosystem vulnerable to low yields, high production cost, degrading soil and water quality, and climatic vagaries. The present study was undertaken on CA-based sustainable intensification of Indian mustard for enhancing inputs efficiencies, farm profitability and sustainability. Permanent beds with residue retention $(\mathrm{PB}+\mathrm{R})$ improved mustard equivalent yield $(11.4 \%)$ and system grain yield (10.6\%) compared to conventional tillage without residue (CT-R). Maize-mustard (Mz-M) increased system grain yield (142.9\%) as well as mustard equivalent yield (60.7\%) compared to fallowmustard (F-M). Mz-M system under $\mathrm{PB}+\mathrm{R}$ increased sustainable yield index $(376.5 \%)$, production efficiency (177.2\%), economic efficiency (94\%) and irrigation water productivity (66\%) compared to F$\mathrm{M}$ under CT-R. PB+R increased soil organic carbon (SOC) stock at $0-15 \mathrm{~cm}(17.7 \%)$ and $15-30 \mathrm{~cm}$ (29.5\%) soil depth compared to CT-R. Intensification of F-M system with green gram-mustard (GG-M) improved SOC at $0-15 \mathrm{~cm}(27.4 \%)$ and $15-30 \mathrm{~cm}(20.5 \%)$ compared to F-M. CA-based cluster beanmustard/GG-M system increased $\mathrm{N}$ productivity, whereas, $\mathrm{P}$ and $\mathrm{K}$ productivity improved with Mz-M system compared to F-M under CT-R. Thus, CA-based Mz-M system should be out-scaled in the traditional rainfed fallow-mustard system to improve the farm production and income on holistic basis to make the country self-sufficient in edible oils.

*Corresponding author (email: rl.choudhary@icar.gov.in/rs.jat@icar.gov.in)
\end{abstract}

\section{Introduction}

Conservation Agriculture is being practiced over 125 million hectare world-wide ${ }^{1}$ and has several reports of reduced production costs, improved water-use efficiency, and sustained or increased crop productivity across the globe in the present era of resource degradation and climate change ${ }^{2-8}$. Sustainable intensification of crops and cropping systems, as one of the principles of conservation agriculture, hold a lot of potential to withstand climatic anomaly, price fluctuation, balanced food supply, natural resource degradation, and fertilizer and pesticide dependence. Conservation agriculture-based system intensification in the vulnerable semi-arid tropics provides opportunities to conserve and utilize the fatiguing natural resources more efficiently, resilience to anomalous climatic events, and to increase productivity and farmers' profitability while minimizing production cost and energy use. Besides this, crop intensification improves the nutritional security of the farm households and reduces the risk of total crop failure in unfavorable or erratic weather situations ${ }^{9}$. In rice-wheat system, CA-based sustainable intensification increased productivity $(10-17 \%)$ and profitability $(24-50 \%)$ at less irrigation water (15$71 \%$ ), energy (17-47\%) and carbon foot prints than conventional practices ${ }^{10}$. Despite of the documented benefits of CA in diverse cropping systems around the globe remains contested ${ }^{11,12}$ under the resource poor and vulnerable smallholder farming systems mainly for the crop residues diversion in various uses ${ }^{12}$. Considering various arguments, the CA must obviously be adapted to local agro-ecological conditions, and farmer capabilities and preferences. Fundamentally, to derive maximum benefit from CA, locationspecific appropriate crop rotations and system-based CA practices need to be standardized ${ }^{13,14}$.

India is $5^{\text {th }}$ largest vegetable oil economy accounting $7.4 \%$ oilseeds, $5.8 \%$ oils and $6.1 \%$ oil meal production, and $9.3 \%$ consumption of edible oils in the world ${ }^{15}$. Vegetable oils are the second most important agricultural economy in India next to cereals growing at a pace of $4.1 \%$ per annum in the last three decades. Despite being the third largest producer (11.3\%) of rapeseed and mustard after Canada and China in the world, India meets $60 \%$ of the domestic edible oil requirements through imports and ranked $7^{\text {th }}$ largest importer of edible oils in the world. The country needs 25 MT of edible oils to meet its 
requirement at the current consumption level of $19 \mathrm{~kg}$ per person per annum. Indian mustard holds sizable contribution, however, the productivity levels are $2 / 3^{\text {rd }}$ of the world level due to large scale cultivation under rainfed situation, biotic and abiotic stresses, and resources crunch ${ }^{16,15}$. The conventional rapeseed \&mustard production system in India largely suffers due to excessive tillage, poor crop establishment and monotonous cropping system which exaggerate the resource degradation and cost of production ${ }^{17,18}$. Indian mustard dominantly grown as winter oilseed under fragile rainfed ecology with intensive land preparation involving multiple passes of discs/tine harrows and planking to create a friable seedbed. Undesired excessive tillage practices for field preparation ${ }^{19}$ leads to breakdown of soil organic carbon ${ }^{20,21}$ which decline the soil fertility and microbial population. It also leads to early exhaustion of soil moisture which is a major apprehension in the rainfed ecology. CA-based crop management systems are mostly scaled-out for major cereal-based cropping systems (rice/maize-wheat), rarely developed for oilseed and pulse-based cropping systems. There is need to develop an alternative holistic management strategy based on ectopic and conservation agriculture principles for enhanced system capacity, biomass production and energy-use efficiency and reduction in carbon foot prints.

Indian mustard, a dominant and versatile oilseed crop of semi-arid tropics, needs incessant system-based approaches at appropriate scale to exploit the metabolic potential while enduring the growing climatic stresses. CA-based sustainable intensification of the traditional fallow-mustard system in the rainfed ecology holds promises to address the shortfall of oilseed and edible oil in the country and reduce the import burden. The present study will provide insights of (i) CA-based system intensification of Indian mustard production under rainfed ecologies, (ii) enhanced inputs and output efficiencies, and (iii) Sustainability, economic viability and soil health in CA-based Indian mustard systems.

\section{Results and discussion \\ Production and economics}

Conservation tillage practices $(\mathrm{PB}+\mathrm{R}$ and $\mathrm{ZT}+\mathrm{R})$ recorded markedly higher $(\mathrm{p}=0.05)($ Table 2$)$ mustard seed yield compared to conventional tillage (CT-R) (Table 1). Permanent bed with residue produced maximum mustard seed yield $\left(3.0 \mathrm{Mgha}^{-1}\right)$ followed by zero tillage with residue $\left(2.8 \mathrm{Mg} \mathrm{ha}^{-1}\right)$ and conventional tillage without residue $\left(2.6 \mathrm{Mg} \mathrm{ha}^{-1}\right)$. $\mathrm{PB}+\mathrm{R}$, though, on par with $\mathrm{ZT}+\mathrm{R}$ increased mustard seed yield by $15.4 \%$ (3-year mean) over the CT-R. Intensification of mustard-based cropping systems through cluster bean (CB-M), green gram (GG-M) and maize (Mz-M) crops during the rainy season (July-September) increased mustard seed yield (3-year mean) compared to fallow-mustard (farmers practice in this region). Though, addition of pearl millet (PM-M) and sesame (S-M) during the rainy season recorded lower mustard seed yield. The highest mustard seed yield was recorded in maizemustard cropping system (3.1 $\mathrm{Mg} \mathrm{ha}^{-1}$ ) (Table 1) followed by CB-M ad GG-M. Bed planting improved yield of mustard as well as crops in the system due to better plant establishment, root development, optimum fertilizer placement, and improved soil physicochemical and biological properties. Higher productivity and profitability in CA-based management was reported in mustard ${ }^{22}$ and sesame-based cropping system ${ }^{23}$ compared to mono-cropping. Permanent bed planting ensured higher mustard yield due to complementary border effects ${ }^{24}$ which are more under residue retention than conventional tillage without residue. Advantage of CA in rice-wheat and maize-wheat systems was reported to enhance the crop productivity, water productivity, profitability, and water saving, compared to CT-based systems ${ }^{25}$.

Rainy season crops recorded higher seed yield (3-year mean across the crops) under PB+R (1.4 $\mathrm{Mg} \mathrm{ha}^{-1}$ ) compared to $\mathrm{ZT}+\mathrm{R}$ ad CT-R (Table 1). Among the cropping systems, maize was found most productive $\left(3.7 \mathrm{Mg} \mathrm{ha}^{-1}\right.$ ) followed by pearl millet, cluster bean, green gram and sesame. Average seed yield of individual crops (cluster bean, green gram, maize, pearl millet and sesame) in rotation with mustard recorded higher under PB+R compared to ZT+R and CT-R (Fig. 1).

Conservation tillage practices increased overall system grain yield (yield of rainy crops and mustard) and recorded higher (3-year mean) $(\mathrm{p}=0.05)$ (Table 2) under $\mathrm{PB}+\mathrm{R}\left(4.3 \mathrm{Mg} \mathrm{ha}^{-1}\right)$ compared to $\mathrm{ZT}+\mathrm{R}\left(4.0 \mathrm{Mg} \mathrm{ha}^{-1}\right)$ and CT-R (3.9 $\left.\mathrm{Mg} \mathrm{ha}^{-1}\right)$ (Table 1). PB+R increased system grain yield by 10.6 and $7.5 \%$ over CT-R and ZT+R, respectively. The highest system grain yield was recorded in Mz-M system $\left(6.8 \mathrm{Mg} \mathrm{ha}^{-1}\right)$ followed by PM-M, CB-M, GG-M, S-M and the lowest in the F-M cropping system (2.8 
$\mathrm{Mg} \mathrm{ha}^{-1}$ ). Mz-M system increased system grain yield by $142.9 \%$ over the F-M system which is the most popular system among the regional farmers. The system productivity in terms of mustard equivalent yield (seed yield of rainy season crops converted to mustard seed yield) was markedly higher (3-year mean) under the $\mathrm{PB}+\mathrm{R}$ (3.9 $\mathrm{Mg} \mathrm{ha}^{-1}$ ) compared to $\mathrm{ZT}+\mathrm{R}$ and $\mathrm{CT}-\mathrm{R}$ (Table 1). Mustard equivalent yield increased by $11.4 \%$ under $\mathrm{PB}+\mathrm{R}$ over the $\mathrm{ZT}+\mathrm{R}$ and $\mathrm{CT}-\mathrm{R}$. The system productivity in terms of mustard equivalent yield of different cropping systems revealed the highest of $\mathrm{Mz}-\mathrm{M}$ ( $4.5 \mathrm{Mg} \mathrm{ha}^{-1}$ ) followed by GG-M, CB-M, PM-M and S-M system and the lowest in the fallow-mustard system $\left(2.8 \mathrm{Mg} \mathrm{ha}^{-1}\right)$.The Mz-M system increased mustard equivalent yield by $60.7 \%$ over fallow-mustard system. This might be due to favorable soil-plant-environment continuum in the permanent beds complementing with residues resulted into higher biomass and system yield. CA-based system reported to increased mustard yield, higher system productivity in the rice-mustard ${ }^{26,27}$.

The conservation tillage practice $(\mathrm{PB}+\mathrm{R})$ showed markedly higher $(3$-year mean) $(\mathrm{p}=0.05)($ Table 2) net profit (1720 US\$ ha ${ }^{-1}$ ) compared to ZT+R (1518 US\$ ha-1) and CT-R (1430 US\$ ha-1) (Table 1). $\mathrm{PB}+\mathrm{R}$ increased net returns by 20.3 and $13.3 \%$ over CT-R and ZT $+\mathrm{R}$, respectively. Crop intensification in rainy season increased the overall net profit over the fallow-mustard system (farmers practice). The highest net return was recorded in Mz-M system (1982 US\$ ha ${ }^{-1}$ ) followed by GG-M, CB-M, PM-M, S$\mathrm{M}$ and the lowest profit was accrued in the fallow-mustard system (1291 USDha ${ }^{-1}$ ). Mz-M system increased net return by $53.5 \%$ over the fallow-mustard system. The relative economic efficiency (REE) was worked out for CA practices and compared to conventional practices. The $\mathrm{PB}+\mathrm{R}$ and $\mathrm{ZT}+\mathrm{R}$ showed the higher REE (20.3 and 6.2\%), respectively in comparison to CT-R (Farmers practice) (Table 1). Among the cropping systems, REE increased with the Mz-M (53.6\%), GG-M (43.7\%) and CB-M (37.7\%) systems, however, decreased with the PM-M (-3.4\%) and S-M (-8.2\%) systems in comparison to fallow-mustard system.

The interaction effects between tillage practices and cropping systems (Fig. 2) showed that Mz-M system under PB+R recorded highest net returns (2169 US\$ ha-1) followed by GG-M (2083 US\$ ha-1) and CB-M (1990 US $\$$ ha $^{-1}$ ) compared to other systems and tillage practices. Mz-M system under PB+R increased net return by $94.2 \%$ over F-M system under CT-R (farmers practice) (3-year mean) (Fig. 2). Increased yield of the component crops in the system under permanent beds with residue and crop diversification might be due to the complementary effects of each other resulted into less production cost and higher net return. Combined, these results clearly demonstrate the potential of CA towards sustainable intensification of crop production to improve future household income and food security ${ }^{28,29}$.Incorporation of maize in the system increased the net profit under permanent beds and residue retention might be due to higher grain yield which accrued higher revenue besides the less cost of production under CA practices.

\begin{tabular}{|c|c|c|c|c|c|c|}
\hline Treatments $^{\mathrm{A}}$ & $\begin{array}{c}\text { Mustard } \\
\text { seed yield } \\
\left(\mathrm{Mg} \mathrm{ha}^{-1}\right)\end{array}$ & $\begin{array}{c}\text { Rainy crops } \\
\text { yield }\left(\mathrm{Mg} \mathrm{ha}^{-1}\right)\end{array}$ & $\begin{array}{c}\text { System grain } \\
\text { yield }\left(\mathrm{Mg}^{-} \mathrm{ha}^{-}\right. \\
\left.{ }^{1}\right)\end{array}$ & $\begin{array}{c}\text { Mustard } \\
\text { equivalent } \\
\text { yield }\left(\mathrm{Mg} \mathrm{ha}^{-1}\right)\end{array}$ & $\begin{array}{l}\text { Net returns } \\
\left(\mathrm{US} \$ \mathrm{ha}^{-1}\right)^{\mathrm{B}}\end{array}$ & $\begin{array}{l}\text { REE } \\
(\%)^{\mathrm{C}}\end{array}$ \\
\hline \multicolumn{7}{|c|}{ Tillage practices } \\
\hline $\mathrm{PB}+\mathrm{R}$ & $3.0^{\mathrm{a} \dagger}$ & $1.4^{\mathrm{a}}$ & $4.3^{\mathrm{a}}$ & $3.9^{\mathrm{a}}$ & $1720^{\mathrm{a}}$ & 20.3 \\
\hline $\mathrm{ZT}+\mathrm{R}$ & $2.8^{\mathrm{ab}}$ & $1.2^{\mathrm{b}}$ & $4.0^{\mathrm{b}}$ & $3.5^{\mathrm{b}}$ & $1518^{b}$ & 6.2 \\
\hline CT-R & $2.6^{\mathrm{b}}$ & $1.2^{\mathrm{b}}$ & $3.9^{\mathrm{b}}$ & $3.5^{\mathrm{b}}$ & $1430^{\mathrm{b}}$ & - \\
\hline \multicolumn{7}{|c|}{ Cropping systems } \\
\hline F-M & $2.8^{\mathrm{c}}$ & 0 & $2.8^{\mathrm{e}}$ & $2.8^{\mathrm{e}}$ & $1291^{\mathrm{d}}$ & - \\
\hline CB-M & $2.9^{\mathrm{b}}$ & $1.0^{\mathrm{c}}$ & $3.9^{\mathrm{b}}$ & $3.9^{\mathrm{c}}$ & $1777^{\mathrm{c}}$ & 37.7 \\
\hline GG-M & $2.9^{\mathrm{b}}$ & $0.8^{\mathrm{d}}$ & $3.8^{\mathrm{c}}$ & $4.2^{\mathrm{b}}$ & $1854^{\mathrm{b}}$ & 43.7 \\
\hline Mz-M & $3.1^{\mathrm{a}}$ & $3.7^{\mathrm{a}}$ & $6.8^{\mathrm{a}}$ & $4.5^{\mathrm{a}}$ & $1982^{\mathrm{a}}$ & 53.6 \\
\hline PM-M & $2.6^{\mathrm{d}}$ & $1.5^{\mathrm{b}}$ & $4.1^{\mathrm{b}}$ & $3.2^{\mathrm{d}}$ & $1247^{\mathrm{de}}$ & -3.4 \\
\hline S-M & $2.4^{\mathrm{e}}$ & $0.6^{\mathrm{e}}$ & $3.0^{\mathrm{d}}$ & $3.2^{\mathrm{d}}$ & $1185^{\mathrm{e}}$ & -8.2 \\
\hline
\end{tabular}


Table 1. Crop yields, system productivity and economics of CA-based Indian mustard systems (3 years mean). ${ }^{\mathrm{A}}$ Refer to Table 7 for treatment description. ${ }^{\mathrm{B}} \mathrm{US} \$=70.34$ INR. ${ }^{\mathrm{C}}$ Relative economic efficiency. ${ }^{\dagger}$ Means followed by a similar lowercase letters within a column are not significantly different at 0.05 level of probability using DMRT.

\begin{tabular}{lcccccccccc}
\hline Source & \multicolumn{4}{c}{$\mathrm{LSD}^{\mathrm{p}} \mathrm{p=0.05)}$} & \multicolumn{4}{c}{$\mathrm{R}^{2}$} \\
\cline { 2 - 11 } & $\mathrm{MSY}^{\mathrm{a}}$ & $\mathrm{RCY}^{\mathrm{b}}$ & $\mathrm{SGY}^{\mathrm{c}}$ & $\mathrm{MEY}^{\mathrm{d}}$ & $\mathrm{NR}^{\mathrm{e}}$ & MSY & RCY & SGY & MEY & NR \\
\hline Tillage practices & 0.2 & 0.03 & 0.1 & 0.1 & 136 & 0.92 & 0.99 & 0.99 & 0.98 & 0.98 \\
Cropping systems & 0.1 & 0.1 & 0.2 & 0.2 & 73 & & & & & \\
\hline
\end{tabular}

Table 2. ANOVA for a Mustard seed yield $\left(\mathrm{Mg} \mathrm{ha}^{-1}\right)$, ${ }^{\mathrm{b}}$ Rainy crops yield $\left(\mathrm{Mg} \mathrm{ha}^{-1}\right),{ }^{\mathrm{c}}$ System grain yield $\left(\mathrm{Mg} \mathrm{ha}^{-1}\right),{ }^{\mathrm{d}}$ Mustard equivalent yield $\left(\mathrm{Mg} \mathrm{ha}^{-1}\right)$, and ${ }^{\mathrm{e}} \mathrm{Net}$ returns $\left(\mathrm{US} \$ \mathrm{ha}^{-1}\right)$.

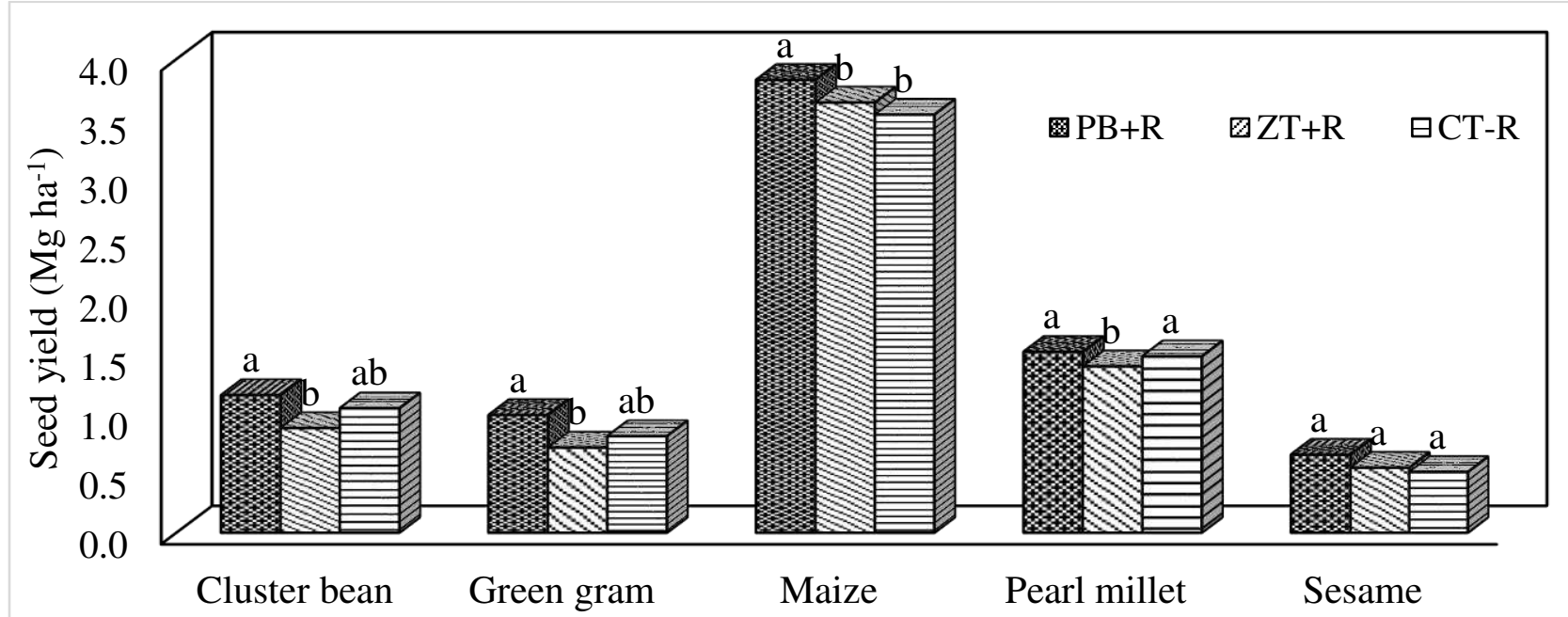

Fig.1. Yield of rainy season crops in Indian mustard-based cropping systems under different CA practices (mean of $3 \mathrm{yrs}$ ).

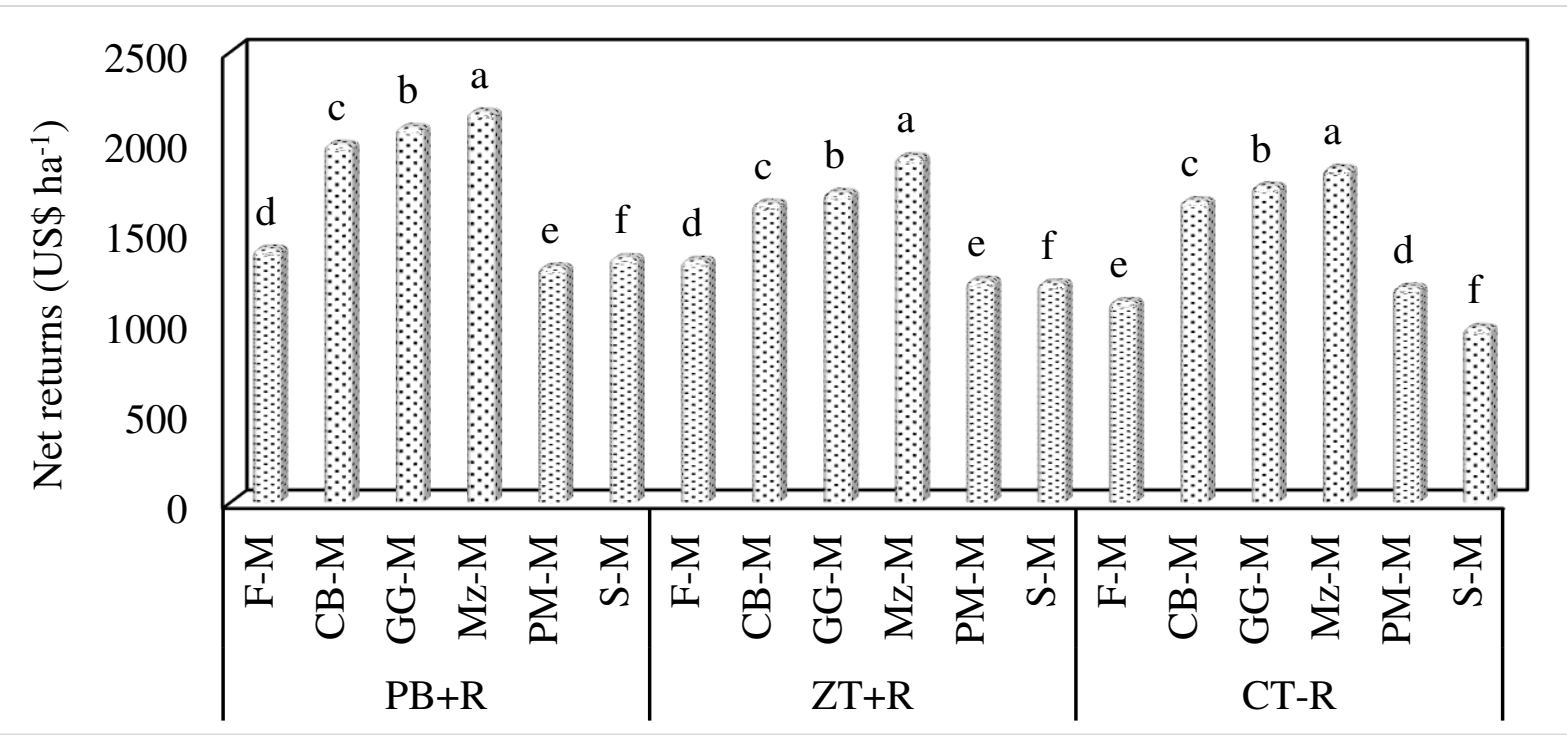

Fig. 2. Net return of different CA-based Indian mustard systems (3-year mean). 


\section{Sustainability and input use efficiencies}

Conservation agriculture practice $(\mathrm{PB}+\mathrm{R})$ found more sustainable compared to $\mathrm{ZT}+\mathrm{R}$ and $\mathrm{CT}-\mathrm{R}$ (3-year mean). $\mathrm{PB}+\mathrm{R}$ recorded higher $(\mathrm{p}=0.05)$ (Table 4$)$ sustainable yield index $(0.41)$ by $13.9 \%$ over the $\mathrm{ZT}+\mathrm{R}$ and CT-R (Table 3). Among the mustard-based cropping systems intensification, Mz-M system recorded the highest SYI (0.75), whereas, found least in fallow-mustard system (0.20) (Table 3). The interaction effects between tillage practices and cropping systems (Fig.3) showed that Mz-M system recorded significantly higher SYI under PB+R (0.81) compared to other systems. Mz-M system under $\mathrm{PB}+\mathrm{R}$ increased SYI by $376.5 \%$ compared to F-M under CT-R (farmers practice). Permanent beds with residue under maize-mustard cropping system reported highest SYI due to higher yields, improved soil conditions, organic carbon build up, and residue incorporation ${ }^{30,31,27}$. It might also be due to higher assimilation of metabolizable $\mathrm{C}$ and $\mathrm{N}$ in crop plants due to residue retention, increased root biomass, and root absorption ${ }^{32}$.

Production per day spread over the crop duration (3-year mean) increased $(\mathrm{p}=0.05)$ (Table 4) evidently under the $\mathrm{PB}+\mathrm{R}$ compared to $\mathrm{ZT}+\mathrm{R}$ and $\mathrm{CT}-\mathrm{R}$ (Table 3). Production efficiency was highest under $\mathrm{PB}+\mathrm{R}\left(15.7 \mathrm{~kg}_{\text {grainday }}{ }^{-1}\right)$ which was 9.0 and $11.3 \%$ more compared to $\mathrm{ZT}+\mathrm{R}$ and CT-R, respectively. Addition of rainy season crops in the system increased production efficiency significantly compared to fallow-mustard (farmer's practices). Mz-M system recorded the highest PE (24.6 kg grainday $\left.^{-1}\right)$ followed by PM-M (14.8 kg grainday $\left.{ }^{-1}\right)$, CB-M (14.3 kg grain day $\left.{ }^{-1}\right)$, GG-M (13.7 kg grain day $\left.^{-1}\right)$ and S-M (10.9 kg grain day $\left.{ }^{-1}\right)$, and lowest in the F-M (10.2 kg grain day $\left.{ }^{-1}\right)$. Mz-M system increased production efficiency by $141.2 \%$ over the fallow-mustard system. Interaction effects showed that Mz-M system also recorded significantly higher production efficiency under $\mathrm{PB}+\mathrm{R}\left(26 \mathrm{~kg}_{\text {grain }}\right.$ day $\left.^{-1}\right)$ compared to other systems and tillage practices (3-year mean) (Fig. 4). Mz-M system under PB+R increased PE by $177.2 \%$ over the F-M under CT-R (farmers practice).

Economic efficiency in terms of US\$ day ${ }^{-1}$ (3-year mean) recorded highest $(\mathrm{p}=0.05)$ (Table 4) in the PB+R (6.4 US\$ day ${ }^{-1}$ ) compared to ZT+R (5.6 US\$ day ${ }^{-1}$ ) and CT-R (5.3 US\$ day ${ }^{-1}$ ). The EE increased by $14.3,20.8 \%$ over the ZT+R and CT-R, respectively (Table 3 ). Among different cropping systems, highest economic efficiency was achieved in Mz-M system (7.3 US\$ day ${ }^{-1}$ ) followed by GG-M $\left(6.9{\left.\text { US } \$ \text { day }^{-1}\right) \text { and CB-M (6.6 US\$ day }}^{-1}\right)$. The EE decreased in case of PM-M (4.6 US\$ day $\left.{ }^{-1}\right)$ and S-M (4.4 US\$ day ${ }^{-1}$ ) compared to F-M system (4.8 US\$ day ${ }^{-1}$ ). The Mz-M system increased the economic efficiency by $52.1 \%$ compared to fallow-mustard system (farmers practice). Again, the interaction effects showed that Mz-M system recorded higher EE under PB+R (8 US\$ day $\left.{ }^{-1}\right)$ compared to other systems and tillage practices (3-year mean) (Fig. 5). Mz-M system under PB+R increased EE by $94 \%$ over the F-M under CT-R (farmers practice). Higher grain yield of Mz-M system under PB+R might have recorded higher production efficiency compared to systems of same duration (270 days) and fallow-mustard as well. Economic efficiency of Mz-M and GG-M systems were higher due to higher grain yield and fetched remunerative sale price besides reduced cost of production in comparison to the conventional tillage practices. The EE decreased in PM-M and S-M system compared to F-M might be due to negative rotation effects and less seed yield of mustard under these systems. Similar results were also reported by $^{19,29}$.

Conservation tillage practice $(\mathrm{PB}+\mathrm{R})$ recorded highest $(\mathrm{p}=0.05)$ (Table 4) irrigation water productivity in terms of $\mathrm{kg}$ grain per $\mathrm{M}^{3}$ of water (3-year mean) compared to $\mathrm{ZT}+\mathrm{R}$ and CT-R (Table 3). $\mathrm{PB}+\mathrm{R}$ recorded IWP $3.14 \mathrm{~kg}_{\text {grainM }}{ }^{-3}$ which was increased by 35.4 and $39.6 \%$ over the $\mathrm{ZT}+\mathrm{R}(2.32 \mathrm{~kg}$

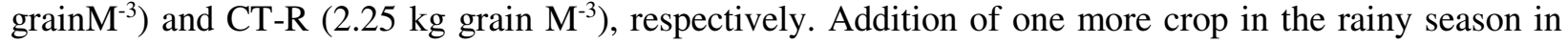
mustard-based systems increased IWP markedly (3-year mean) and recorded highest in the Mz-M system (2.94 $\mathrm{kg}$ grain $\mathrm{M}^{-3}$ ). Mz-M system increased IWP by $18.1 \%$ compared to fallow-mustard system (farmers practice). The interaction effects between tillage practices and cropping systems (3-year mean) (Fig. 6) showed that Mz-M, system under $\mathrm{PB}+\mathrm{R}$ recorded highest IWP $\left(3.57 \mathrm{~kg}_{\text {grain }} \mathrm{M}^{-3}\right.$ ) compared to other treatments. The Mz-M system under PB+R increased IWP by $66 \%$ over the F-M under CT-R (farmers practice).CA-based maize-mustard system reported higher IWP might be due to less water evaporation from the soil surface and higher moisture retention for longer period under the residue cover compared to frequent tillage in the CT plots with more evaporation loss of soil moisture. Higher moisture retention in 
residue treatment helped proper germination/ emergence of mustard seedlings and stand establishment, better seedlings growth and, ultimately, higher yields of mustard. Crop residues led to better equilibrium between macro- and micro-(3-year mean) porosity, root development, biomass production, moisture content, yield and water productivity ${ }^{27,33-35}$.

\begin{tabular}{|c|c|c|c|c|}
\hline Treatments $^{\mathrm{A}}$ & $\mathrm{SYI}^{\mathrm{B}}$ & $\mathrm{PE}\left(\mathrm{kg} \text { grain } \text { day }^{-1}\right)^{\mathrm{C}}$ & EE (US\$ day $\left.{ }^{-1}\right)^{\mathrm{D}}$ & IWP $\left(\mathrm{kg} \text { grain } \mathrm{M}^{-3}\right)^{\mathrm{E}}$ \\
\hline \multicolumn{5}{|c|}{ Tillage practices } \\
\hline $\mathrm{PB}+\mathrm{R}$ & $0.41^{\mathrm{a} \dagger}$ & $15.7^{\mathrm{a}}$ & $6.4^{\mathrm{a}}$ & $3.14^{\mathrm{a}}$ \\
\hline $\mathrm{ZT}+\mathrm{R}$ & $0.36^{\mathrm{b}}$ & $14.4^{\mathrm{b}}$ & $5.6^{\mathrm{b}}$ & $2.32^{\mathrm{b}}$ \\
\hline CT-R & $0.36^{\mathrm{b}}$ & $14.1^{\mathrm{b}}$ & $5.3^{\mathrm{b}}$ & $2.25^{\mathrm{b}}$ \\
\hline \multicolumn{5}{|c|}{ Cropping systems } \\
\hline F-M & $0.20^{f}$ & $10.2^{\mathrm{e}}$ & $4.8^{\mathrm{d}}$ & $2.49^{c}$ \\
\hline CB-M & $0.36^{\mathrm{c}}$ & $14.3^{\mathrm{b}}$ & $6.6^{\mathrm{c}}$ & $2.86^{\mathrm{a}}$ \\
\hline GG-M & $0.34^{\mathrm{d}}$ & $13.7^{\mathrm{c}}$ & $6.9^{b}$ & $2.75^{\mathrm{b}}$ \\
\hline Mz-M & $0.75^{\mathrm{a}}$ & $24.6^{\mathrm{a}}$ & $7.3^{\mathrm{a}}$ & $2.94^{\mathrm{a}}$ \\
\hline PM-M & $0.38^{\mathrm{b}}$ & $14.8^{\mathrm{b}}$ & $4.6^{\mathrm{de}}$ & $2.2^{\mathrm{d}}$ \\
\hline S-M & $0.23^{\mathrm{e}}$ & $10.9^{\mathrm{d}}$ & $4.4^{\mathrm{e}}$ & $2.17^{\mathrm{d}}$ \\
\hline
\end{tabular}

Table 3. Sustainability, production and economic efficiency, and water productivity under different CAbased Indian mustard systems (mean of $3 \mathrm{yrs}$ ). ${ }^{\mathrm{A}}$ Refer Table 7 for treatment description. ${ }^{\mathrm{B}}$ Sustainable yield index. ${ }^{\mathrm{C}}$ Production efficiency. ${ }^{\mathrm{D}}$ Economic efficiency. ${ }^{\mathrm{E}}$ Irrigation water productivity. ${ }^{\dagger}$ Means followed by a similar lowercase letters within a column are not significantly different at 0.05 level of probability using DMRT.

\begin{tabular}{lcccccccc}
\hline Source & \multicolumn{4}{c}{ LSD $(\mathrm{p}=0.05)$} & \multicolumn{3}{c}{$\mathrm{R}^{2}$} \\
\cline { 2 - 9 } & $\mathrm{SYI}^{\mathrm{a}}$ & $\mathrm{PE}^{\mathrm{b}}$ & $\mathrm{EE}^{\mathrm{c}}$ & $\mathrm{IWP}^{\mathrm{d}}$ & $\mathrm{SYI}$ & $\mathrm{PE}$ & $\mathrm{EE}$ & $\mathrm{IWP}$ \\
\hline Tillage practices & 0.03 & 0.77 & 0.50 & 0.14 & 0.99 & 0.99 & 0.97 & 0.98 \\
Cropping systems & 0.02 & 0.47 & 0.27 & 0.08 & & & & \\
\hline
\end{tabular}

Table 4. ANOVA for ${ }^{a}$ Sustainable yield index. ${ }^{b}$ Production efficiency. ${ }^{c}$ Economic efficiency. ${ }^{\mathrm{d}}$ Irrigation water productivity. 


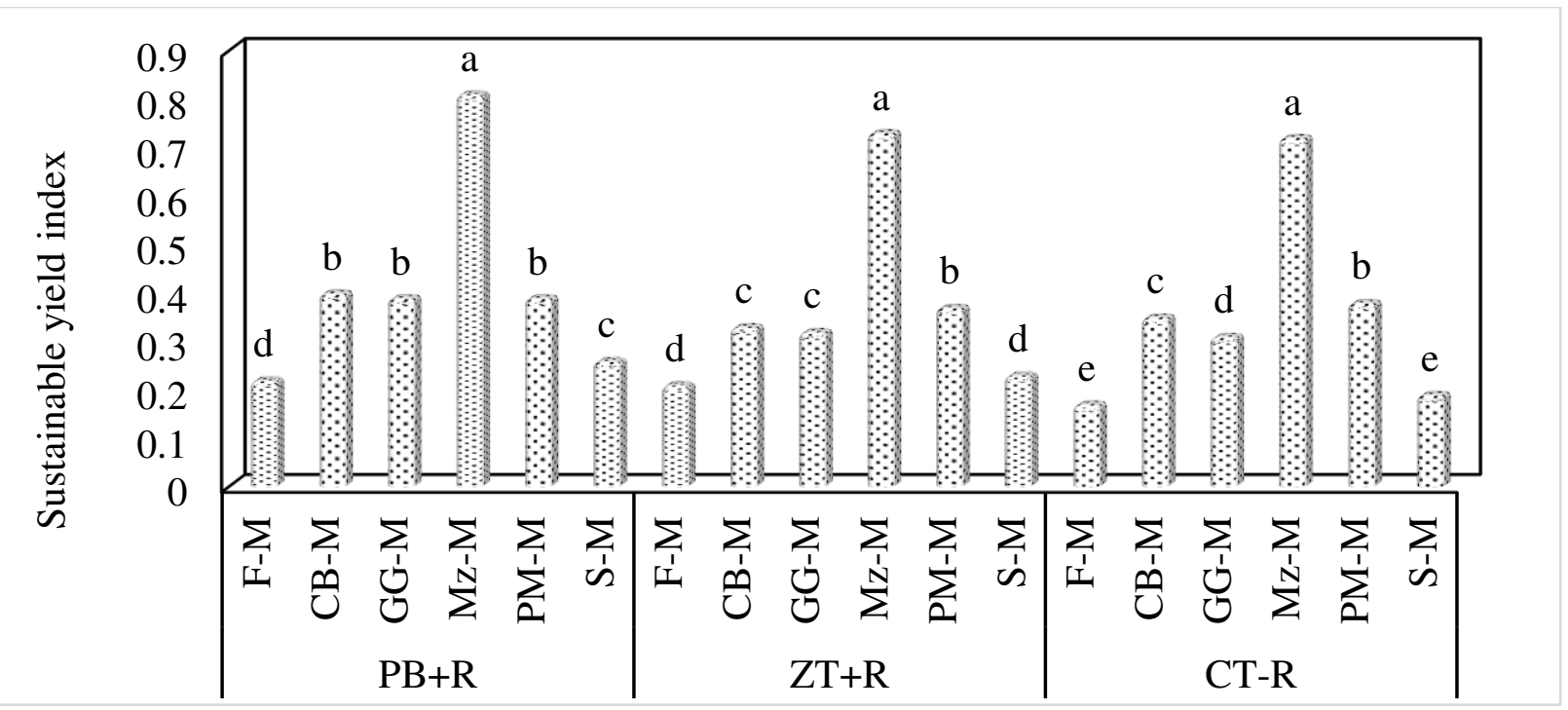

Fig. 3. Sustainable yield index of different CA-based Indian mustard-based systems (3-year mean).

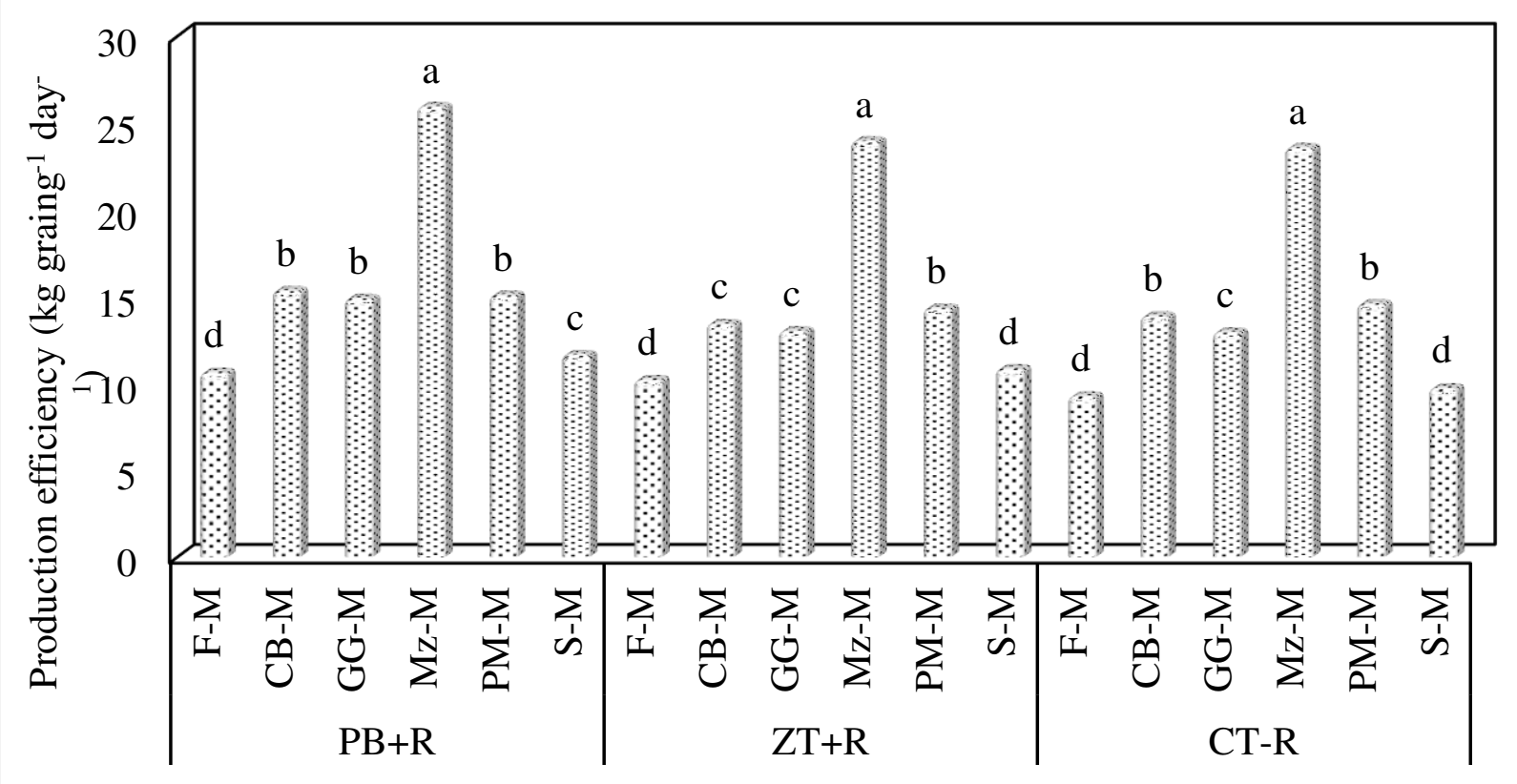

Fig. 4. Production efficiency of CA-based Indian mustard systems (3-year mean). 


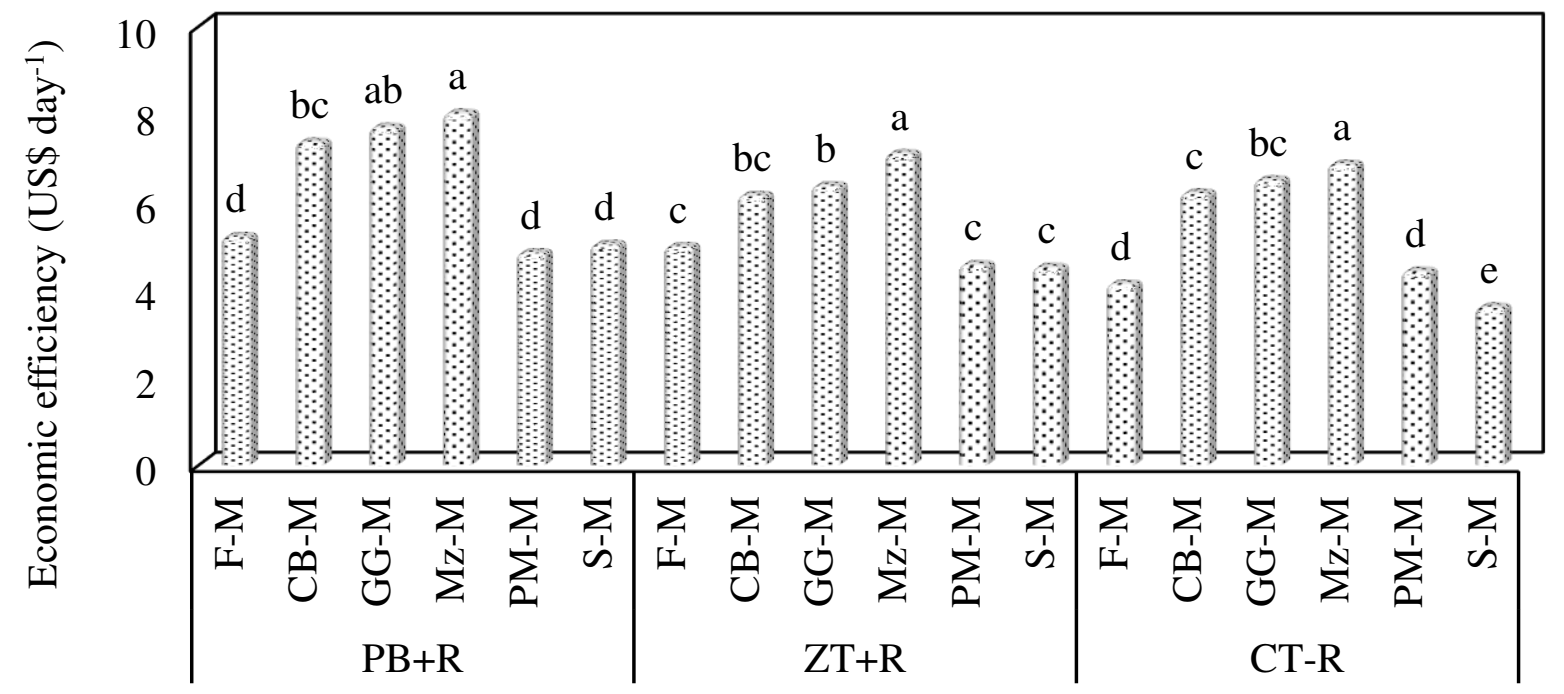

Fig. 5. Economic efficiency of CA-based Indian mustard systems (3-year mean).

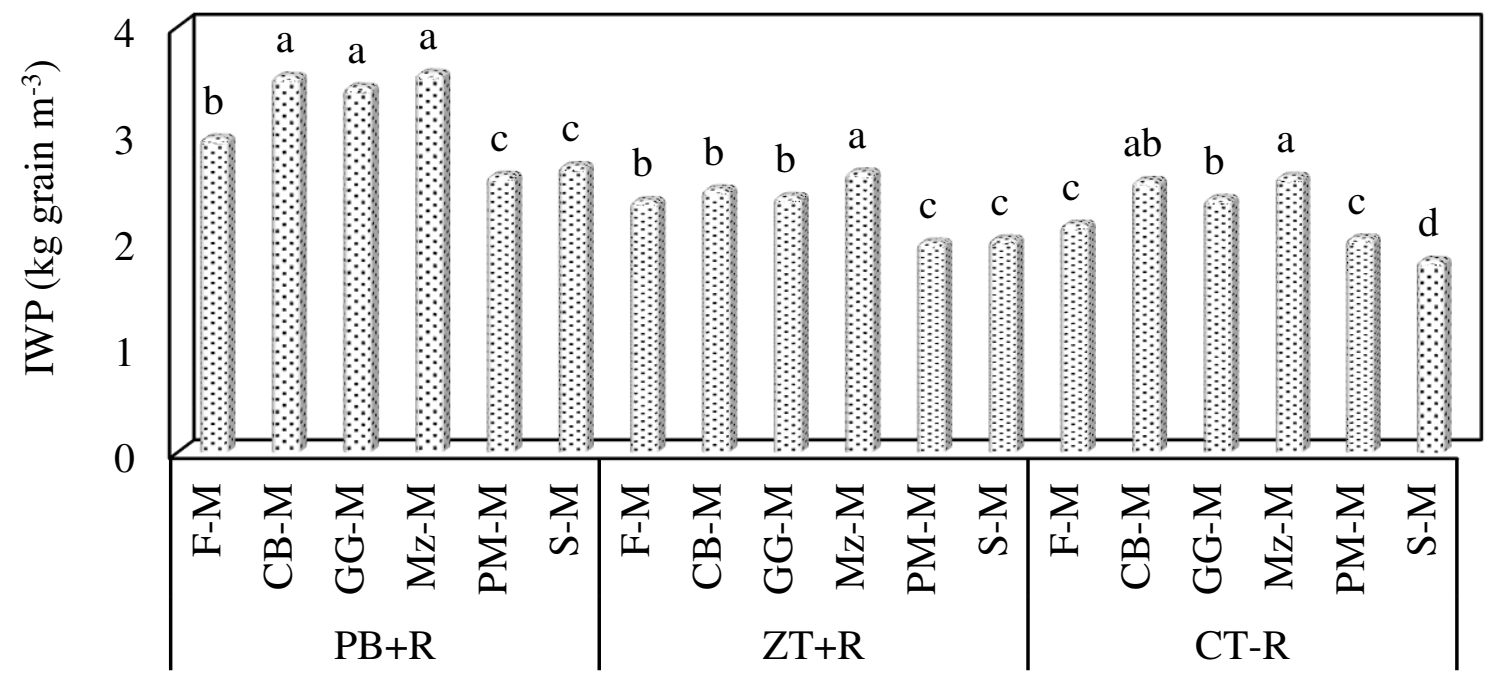

Fig. 6. Irrigation water productivity of CA-based Indian mustard systems (3-year mean).

\section{Soil organic carbon stock and nutrient productivity}

Improvement in soil organic carbon (SOC) is a major goal of adopting CA practices. Conservation tillage practices significantly $(\mathrm{p}=0.05)$ (Table 6$)$ enhanced the soil organic carbon stock $\left(\mathrm{Mg} \mathrm{ha}^{-1}\right)$ compared to conventional tillage at two plow layers $(0-15$ and $15-30 \mathrm{~cm})$ (Table 5). At 0-15 cm soil depth, $\mathrm{PB}+\mathrm{R}\left(11.3 \mathrm{Mg} \mathrm{ha}^{-1}\right)$ though, on par with $\mathrm{ZT}+\mathrm{R}\left(10.6 \mathrm{Mg} \mathrm{ha}^{-1}\right)$ increased SOC by $17.7 \%$ over CT-R $\left(9.6 \mathrm{Mg} \mathrm{ha}^{-1}\right)$ and $28.4 \%$ over the initial value $\left(8.8 \mathrm{Mg} \mathrm{ha}^{-1}\right)$. System intensification influenced SOC markedly at $0-15 \mathrm{~cm}$ soil depth and recorded highest in GG-M system (12.1 $\left.\mathrm{Mg} \mathrm{ha}^{-1}\right)$ followed by Mz-M (10.9 $\mathrm{Mg} \mathrm{ha}^{-1}$ ) and CB-M (10.7 $\left.\mathrm{Mg} \mathrm{ha}^{-1}\right)$, however, recorded lowest $\left(9.5 \mathrm{Mg} \mathrm{ha}^{-1}\right.$ ) in fallow-mustard system. GG-M system increased SOC by $27.4 \%$ over fallow-mustard system and $37.5 \%$ over the initial value (8.8 $\mathrm{Mg} \mathrm{ha}^{-1}$ ) (3-year mean). SOC at $15-30 \mathrm{~cm}$ soil depth decreased compared to $0-15 \mathrm{~cm}$ depth and recorded highest in $\mathrm{PB}+\mathrm{R}\left(10.1 \mathrm{Mg} \mathrm{ha}^{-1}\right)$. Conservation tillage practices $(\mathrm{PB}+\mathrm{R}$ and $\mathrm{ZT}+\mathrm{R})$ increased SOC significantly over the CT-R by 29.5 and $19.2 \%$ (3-year mean), respectively. System intensification 
also increased SOC at 15-30 cm soil depth and recorded highest in GG-M system (10.0 Mg ha $\left.{ }^{-1}\right)$ followed by CB-M (9.4 $\left.\mathrm{Mg} \mathrm{ha}^{-1}\right)$ and Mz-M (9.3 $\left.\mathrm{Mg} \mathrm{ha}^{-1}\right)$. SOC stock increased in GG-M by $20.5 \%$ over the fallow-mustard (3-year mean). SOC stock improved in all the system at both the plow layers $0-15 \mathrm{~cm}$ and $15-30 \mathrm{~cm}$ over the initial value of 8.8 and $7.1 \mathrm{Mg} \mathrm{ha}^{-1}$, respectively. Soil structure and soil organic matter (SOM) are the two most dynamic soil properties, and are highly sensitive to agricultural management practices $^{36}$. However, the detrimental effects of continuous tillage could be reduced by CA, which could accelerate soil aggregation and carbon sequestration ${ }^{37}$. Soil organic carbon as a soil health indicator influence the biological activity and soil suitability in terms of physical and chemical properties. Inclusion of legumes (GG \& $\mathrm{CB}$ ) in the mustard-based cropping systems reported higher SOC and PFPn might be due to legume effect, low $\mathrm{C}: \mathrm{N}$ ratio residue of green gram and cluster bean increased the SOC and residual $\mathrm{N}$ after harvest. Residue incorporation/retention helps in improving SOC through soil aggregate size and stability $38,39,26$. The minimum SOC under CT could be due to excessive tillage led to inversion of the top soil, SOM degradation by aggregates disruption, higher oxidation and mineralization of SOM, and consequent release of nutrients ${ }^{40}$.

Partial factor productivity (PFP) in terms of unit seed yield per unit of nitrogen, phosphorus and potassium applied, increased markedly $(\mathrm{p}=0.05)$ (Table 6) under conservation tillage practices. $\mathrm{PB}+\mathrm{R}$, though, on par with ZT+R, recorded the highest PFPn (34.8 $\left.\mathrm{kgha}^{-1}\right)$, PFPp (42.4 kg ha-1) and PFPk (59.7 $\mathrm{kg} \mathrm{ha}^{-1}$ ) which was $12.3,12.5$ and $12 \%$ higher over the CT-R, respectively (3-year mean) (Table 5). Intensification of fallow-mustard system with legumes (CB-M and GG-M) markedly increased the PFPn, whereas, PFPp and PFPk were higher under Mz-M system (3-year mean). PFPn recorded higher under CB-M (39.4 kg ha') followed by GG-M (37.6 kg ha') compared to fallow-mustard $\left(34.9 \mathrm{~kg} \mathrm{ha}^{-1}\right)$. Whereas, intensification with maize, pearl millet and sesame in mustard-based systems recorded less PFPn compared to fallow-mustard system. The PFPp and PFPk were recorded highest under Mz-M system (48.2 and $75.0 \mathrm{~kg} \mathrm{ha}^{-1}$ ) compared to fallow-mustard system (46.5 and $69.8 \mathrm{~kg} \mathrm{ha}^{-1}$ ), respectively (3-year mean). Except Mz-M, other systems recorded less PFPp and PFPk compared to fallow-mustard system. The PFPn was recorded in CB-M and GG-M due to their legume effect in the rotation, whereas, PFPp and PFPk were higher in Mz-M system due to higher rate of residue incorporation (Table 8).

Combined, these results clearly demonstrate the potential of CA to simultaneously increase yield, diversify crop production and improve soil quality which should support a move towards sustainable intensification of crop production to improve future household income and food security.

\begin{tabular}{|c|c|c|c|c|c|}
\hline \multirow[t]{2}{*}{ Treatments $^{\mathrm{A}}$} & \multicolumn{2}{|c|}{ Soil organic carbon $\left(\mathrm{Mg} \mathrm{ha}^{-1}\right)$} & \multicolumn{3}{|c|}{ Partial factor productivity $\left(\mathrm{kg} \mathrm{ha}^{-1}\right)$} \\
\hline & $0-15 \mathrm{~cm}$ soil depth & $15-30 \mathrm{~cm}$ soil depth & $\operatorname{PFPn}^{\mathrm{B}}$ & PFPp $^{\mathrm{C}}$ & $\mathrm{PFPk}^{\mathrm{D}}$ \\
\hline \multicolumn{6}{|c|}{ Tillage practice } \\
\hline $\mathrm{PB}+\mathrm{R}$ & $11.3^{\mathrm{a} \dagger}$ & $10.1^{\mathrm{a}}$ & $34.8^{\mathrm{a}}$ & $42.4^{\mathrm{a}}$ & $59.7^{\mathrm{a}}$ \\
\hline $\mathrm{ZT}+\mathrm{R}$ & $10.6^{\mathrm{a}}$ & $9.3^{\mathrm{b}}$ & $31.9^{\mathrm{b}}$ & $39.0^{\mathrm{b}}$ & $55.1^{\mathrm{b}}$ \\
\hline CT-R & $9.6^{\mathrm{b}}$ & $7.8^{\mathrm{c}}$ & $31.0^{\mathrm{b}}$ & $37.7^{\mathrm{b}}$ & $53.3^{\mathrm{b}}$ \\
\hline \multicolumn{6}{|c|}{ Cropping system } \\
\hline F-M & $9.5^{\mathrm{d}}$ & $8.3^{\mathrm{c}}$ & $34.9^{\mathrm{c}}$ & $46.5^{\mathrm{b}}$ & $69.8^{\mathrm{b}}$ \\
\hline CB-M & $10.7^{\mathrm{b}}$ & $9.4^{\mathrm{ab}}$ & $39.4^{\mathrm{a}}$ & $39.4^{\mathrm{c}}$ & $49.2^{\mathrm{c}}$ \\
\hline GG-M & $12.1^{\mathrm{a}}$ & $10.0^{\mathrm{a}}$ & $37.6^{\mathrm{b}}$ & $37.8^{\mathrm{d}}$ & $47.2^{\mathrm{d}}$ \\
\hline Mz-M & $10.9^{b}$ & $9.3^{\mathrm{ab}}$ & $33.8^{\mathrm{d}}$ & $48.2^{\mathrm{a}}$ & $75.0^{\mathrm{a}}$ \\
\hline PM-M & $10.3^{\mathrm{bc}}$ & $8.8^{\mathrm{bc}}$ & $22.6^{\mathrm{f}}$ & $29.0^{\mathrm{e}}$ & $45.1^{\mathrm{e}}$ \\
\hline S-M & $9.9^{\text {cd }}$ & $8.6^{\mathrm{c}}$ & $27.1^{\mathrm{e}}$ & $37.3^{\mathrm{d}}$ & $49.8^{c}$ \\
\hline
\end{tabular}

Table 5. Soil organic carbon stock and partial factor productivity of NPK influenced with CA-based Indian mustard systems (3-year mean). ${ }^{\text {A}}$ Refer Table 7 for treatment description. ${ }^{\text {B}}$ Partial factor productivity of N. ${ }^{C}$ Partial factor productivity of P. ${ }^{D}$ Partial factor productivity of K. ${ }^{\dagger}$ Means followed by a similar lowercase letters within a column are not significantly different at 0.05 level of probability using DMRT. Initial SOC at 0-15 cm- 8.8 and at $15-30 \mathrm{~cm}-7.1 \mathrm{Mg} \mathrm{ha}^{-1}$. 


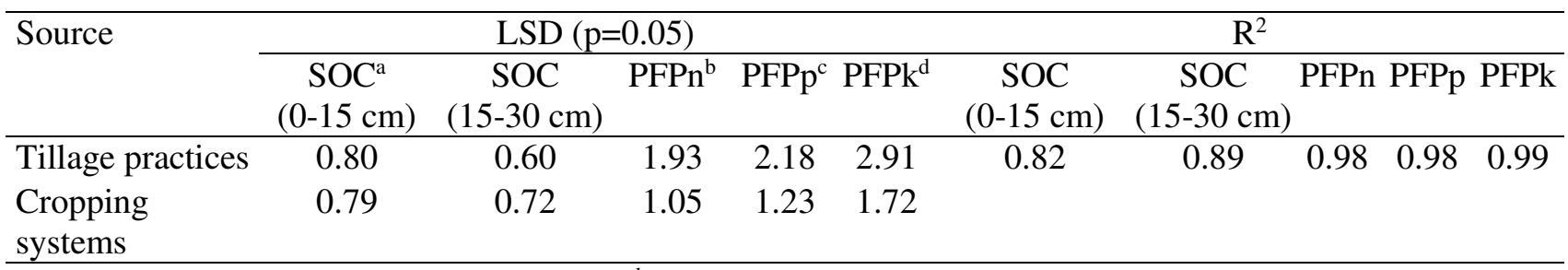

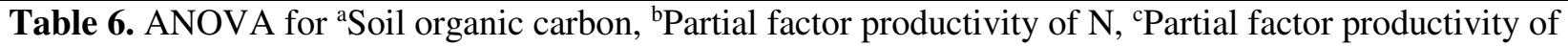
$\mathrm{P}$, and ${ }^{\mathrm{d}}$ Partial factor productivity of $\mathrm{K}$.

\section{Conclusion}

Conservation tillage practices in mustard-based cropping systems achieved higher mustard yield as well as system-based input/output productivity and profitability. Intensification of conventional fallowmustard system with maize-mustard system under $\mathrm{CA}$ based management $(\mathrm{PB}+\mathrm{R})$ proved to be a better alternative with respect to sustainability $(+377 \%)$, production efficiency $(+177 \%)$, economic efficiency $(+94 \%)$ and water productivity $(+66 \%)$. Conservation tillage and system intensification improved the SOC stock and NPK factor productivity compared to conventional fallow-mustard system which was fatigued with low SOC and PFPnpk due to higher tillage operations and no residue incorporation. Sustainable intensification of CT-based fallow-mustard systems through the CA-based maize-mustard system provides excellent opportunities to increase the system efficiency, farm income, soil health and simultaneously to reduce the government burden on import of edible oils.

\section{METHODS}

\section{Study site, climate and soil}

The experiment was conducted for 3-year (2016-17-2018-19) at the research farm, ICARDirectorate of Rapeseed-Mustard Research, Bharatpur located at $77^{\circ} 3^{\prime} \mathrm{E}, 27^{\circ} 15^{\prime} \mathrm{N}$ and 178.37 meter above mean sea level at same location and set of treatments. The climate is semi-arid, characterized with wide range of temperature between summer and winter. The meteorological observations were recorded daily and averaged to monthly during the crop growth period (July-September for rainy season crops and October-March for mustard crop) and presented in Fig.7. The maximum temperature during the crop growing season fluctuated between 20.5 in January to $36.3{ }^{\circ} \mathrm{C}$ in October, and minimum temperature between 7.0 January to $-27.4{ }^{\circ} \mathrm{C}$ in July. The rainfall mostly $(75 \%)$ received during the south-west monsoon (July-September) and varied from 600, 242 and 898 mm during 2016-17, 2017-18 and 2018-19, respectively. Winter rains were also received during the month of January which are very beneficial for the mustard crop growth and development at this stage. The soil $\mathrm{pH}$ and $\mathrm{EC}$ of the experimental site were 8.3 and $1.3 \mathrm{dS} \mathrm{m}^{-1}$, respectively. The soil samples were collected at the time of sowing and analyzed poor in organic carbon $\left(2.4 \mathrm{~g} \mathrm{~kg}^{-1}\right)$ and available $\mathrm{N}\left(126.3 \mathrm{~kg} \mathrm{ha}^{-1}\right)$, while medium in $0.5 \mathrm{~N} \mathrm{NaHCO} 3$ extractable $\mathrm{P}\left(17.2 \mathrm{~kg} \mathrm{ha}^{-1}\right)$ and 1.0N NH4OAc exchangeable $\mathrm{K}\left(149.3 \mathrm{~kg} \mathrm{ha}^{-1}\right)$. The bulk density of soil was $1.52 \mathrm{Mg}$ $\mathrm{m}^{-3}$. 


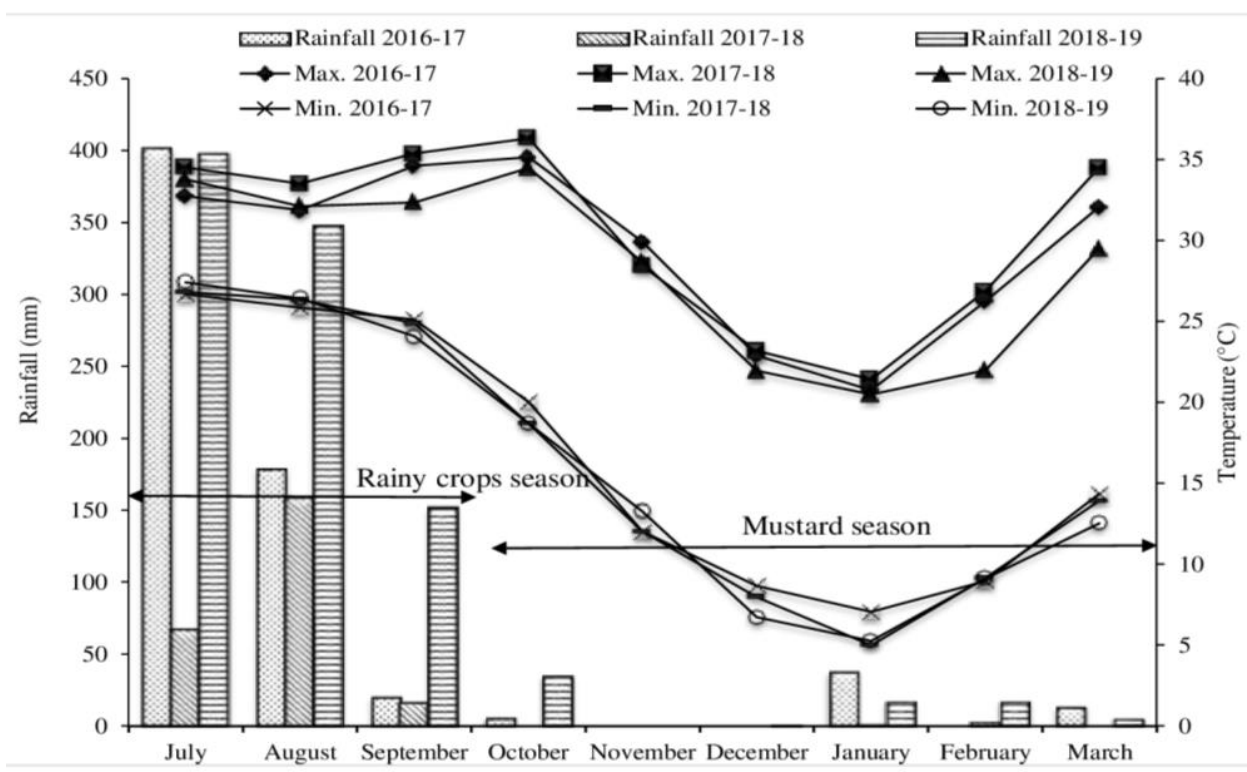

Fig.7. Monthly maximum and minimum temperature, and rainfall during the crop growing seasons (2016-17, 2017-18 and 2018-19). Source: Agromet Observatory, ICAR-DRMR, Bharatpur, Rajasthan (India).

\section{Experimental design and treatments}

The treatment comprised of three conservation agriculture practices [Permanent beds with residue retention $(\mathrm{PB}+\mathrm{R})$; Zero tillage with residue retention $(\mathrm{ZT}+\mathrm{R})$, and conventional tillage without residue retention (CT-R)] and six Indian mustard based cropping systems [fallow-mustard (F-M); cluster bean (Cyamopsis tetragonolobaL.)-mustard (CB-M); green gram (Vigna radiate L.)-mustard (GG-M); maize (Zea mays L.)-mustard (Mz-M); Pearl millet (Pennisetum glaucum (L.) R. Br.)-mustard (PM-M); and sesame (Sesamum indicumL.)-mustard (S-M)]. The treatments consisting 18 interactions were allocated in the split-plot design after randomization, and replicated three times in the permanent plots.

\section{Crop establishment}

The experiment was initiated with deep plowing $(30 \mathrm{~cm})$ with chisel plough to break the hard pan and leveled the soil surface. The rainy season crops were sown as per standard practices and treatments of interest (Table 7). The raised beds were prepared and sown the crops simultaneously with raised bed planter attached with seed-cum-fertilizer drill. These beds were maintained for succeeding crops in cycle as permanent beds. In zero tillage plots, the crops were sown with zero till planter attached with seedcum-fertilizer drill. The conventional tillage crops were sown after sequential tillage operations like harrowing (1), spring-tyne cultivator (5) and leveling (3) as the farmers' practicing in the region.

The rainy season crops were sown in the first week of July after monsoon rains in all the three years. The cluster bean (cv. RGC 1003), green gram (cv. IPM 2-3), pearl millet (cv. RHB 173) and sesame (cv. HT 1) were planted at $30 \mathrm{~cm}$ row to row and $10 \mathrm{~cm}$ plant distance with a seed rate of $15,12,4$ and $4 \mathrm{~kg} \mathrm{ha}^{-1}$, respectively in the CT and ZT plots. While, these crops were planted in two rows at 18.75 $\mathrm{cm}$ spacing in PB plots. The maize crop (cv. QPM 1) was planted with $20 \mathrm{~kg}$ seeds ha ${ }^{-1}$ at $67.5 \mathrm{~cm}$ row to row and $20 \mathrm{~cm}$ plant to plant distance in CT, ZT and PB plots. The dry season, Indian mustard was sown in the same plots as per the tillage treatments (CT, ZT and PB) after the harvest of rainy season crops in the cycle. Indian mustard var. RH 749 was used as test crop in all the years and planted in the first week of October with a seed rate of $4 \mathrm{~kg} \mathrm{ha}^{-1}$ at $45 \mathrm{~cm}$ row to row and $15 \mathrm{~cm}$ plant to plant distance in the CT and ZT plots. Whereas, two rows of mustard were planted in PB plots at $18.75 \mathrm{~cm}$ row to row and $15 \mathrm{~cm}$ 
plant to plant distance. Each crop was accommodated in $15 \times 6.4 \mathrm{~m}$ gross plot area and plant and soil observations were taken from $14 \times 5.4$ m net sown area of each treatment.

\begin{tabular}{|c|c|c|c|c|c|c|c|}
\hline \multirow{2}{*}{$\begin{array}{l}\text { Crop } \\
\text { rotation }\end{array}$} & \multirow[t]{2}{*}{ Crop } & \multicolumn{3}{|c|}{ Tillage } & \multicolumn{3}{|c|}{ Crop establishment } \\
\hline & & PB & $\mathrm{ZT}$ & CT & PB & $\mathrm{ZT}$ & CT \\
\hline F-M & Mustard & $\begin{array}{l}\text { One pass with } \\
\text { permanent beds } \\
\text { with planter }\end{array}$ & $\begin{array}{l}\text { One pass } \\
\text { zero till } \\
\text { drill }\end{array}$ & $\begin{array}{l}3 \text { passes } \\
\text { of } \\
\text { cultivator }\end{array}$ & $\begin{array}{l}\text { Planted 2-rows } \text { on } \\
\text { permanent beds }(67.5 \\
\mathrm{cm}) \text { at } 30 \times 15 \quad \mathrm{~cm} \\
\text { spacing with multi-crop } \\
\text { planter }\end{array}$ & $\begin{array}{l}\text { Sowing with } \\
\text { Zero till drill } \\
\text { at } 45 \times 15 \mathrm{~cm} \\
\text { spacing }\end{array}$ & $\begin{array}{l}\text { Sowing with } \\
\text { seed drill at } \\
45 \times 15 \mathrm{~cm} \\
\text { spacing }\end{array}$ \\
\hline CB-M & $\begin{array}{c}\text { Cluster } \\
\text { bean }\end{array}$ & $\begin{array}{l}\text { One pass with } \\
\text { permanent beds } \\
\text { with planter }\end{array}$ & $\begin{array}{l}\text { One pass } \\
\text { zero till } \\
\text { drill }\end{array}$ & $\begin{array}{l}3 \text { passes } \\
\text { of } \\
\text { cultivator }\end{array}$ & $\begin{array}{l}\text { Planted 2-rows } \\
\text { permanent beds }(67.5 \\
\mathrm{cm}) \text { at } 30 \times 10 \quad \mathrm{~cm} \\
\text { spacing with multi-crop } \\
\text { planter }\end{array}$ & $\begin{array}{l}\text { Sowing with } \\
\text { Zero till drill } \\
\text { at } 30 \times 10 \mathrm{~cm} \\
\text { spacing }\end{array}$ & $\begin{array}{l}\text { Sowing with } \\
\text { seed drill at } \\
30 \times 10 \mathrm{~cm} \\
\text { spacing }\end{array}$ \\
\hline GG-M & $\begin{array}{l}\text { Green } \\
\text { gram }\end{array}$ & $\begin{array}{l}\text { One pass with } \\
\text { permanent beds } \\
\text { with planter }\end{array}$ & $\begin{array}{l}\text { One pass of } \\
\text { zero till } \\
\text { drill }\end{array}$ & $\begin{array}{l}3 \text { passes } \\
\text { of } \\
\text { cultivator }\end{array}$ & $\begin{array}{l}\text { Planted 2-rows } \\
\text { permanent beds }(67.5 \\
\mathrm{cm}) \text { at } 30 \times 10 \quad \mathrm{~cm} \\
\text { spacing with multi-crop } \\
\text { planter }\end{array}$ & $\begin{array}{l}\text { Sowing with } \\
\text { Zero till drill } \\
\text { at } 30 \times 10 \mathrm{~cm} \\
\text { spacing }\end{array}$ & $\begin{array}{l}\text { Sowing with } \\
\text { seed drill at } \\
30 \times 10 \mathrm{~cm} \\
\text { spacing }\end{array}$ \\
\hline Mz-M & Maize & $\begin{array}{l}\text { One pass of } \\
\text { permanent beds } \\
\text { with planter }\end{array}$ & $\begin{array}{l}\text { One pass of } \\
\text { zero till } \\
\text { drill }\end{array}$ & $\begin{array}{l}3 \text { passes } \\
\text { of } \\
\text { cultivator }\end{array}$ & $\begin{array}{l}\text { Planted single row on } \\
\text { permanent beds }(67.5 \\
\mathrm{cm}) 20 \mathrm{~cm} \text { plant spacing } \\
\text { with multi-crop planter }\end{array}$ & $\begin{array}{l}\text { Sowing with } \\
\text { Zero till drill } \\
\text { at } 60 \times 20 \mathrm{~cm} \\
\text { spacing } \\
\end{array}$ & $\begin{array}{l}\text { Sowing with } \\
\text { seed drill at } \\
60 \times 20 \mathrm{~cm} \\
\text { spacing } \\
\end{array}$ \\
\hline PM-M & $\begin{array}{l}\text { Pearl } \\
\text { millet }\end{array}$ & $\begin{array}{l}\text { One pass of } \\
\text { permanent beds } \\
\text { with planter }\end{array}$ & $\begin{array}{l}\text { One pass of } \\
\text { zero till } \\
\text { drill }\end{array}$ & $\begin{array}{l}3 \text { passes } \\
\text { of } \\
\text { cultivator }\end{array}$ & $\begin{array}{l}\text { Planted 2-rows } \text { on } \\
\text { permanent beds }(67.5 \\
\mathrm{cm}) \text { at } 30 \times 10 \quad \mathrm{~cm} \\
\text { spacing with multi-crop } \\
\text { planter }\end{array}$ & $\begin{array}{l}\text { Sowing with } \\
\text { Zero till drill } \\
\text { at } 30 \times 10 \mathrm{~cm} \\
\text { spacing }\end{array}$ & $\begin{array}{l}\text { Sowing with } \\
\text { seed drill at } \\
30 \times 10 \mathrm{~cm} \\
\text { spacing }\end{array}$ \\
\hline S-M & Sesame & $\begin{array}{l}\text { One pass of } \\
\text { permanent beds } \\
\text { with planter }\end{array}$ & $\begin{array}{l}\text { One pass of } \\
\text { zero till } \\
\text { drill }\end{array}$ & $\begin{array}{l}3 \text { passes } \\
\text { of } \\
\text { cultivator }\end{array}$ & $\begin{array}{l}\text { Planted 2-rows } \\
\text { permanent beds }(67.5 \\
\mathrm{cm}) \text { at } 30 \times 10 \quad \mathrm{~cm} \\
\text { spacing with multi-crop } \\
\text { planter }\end{array}$ & $\begin{array}{l}\text { Sowing with } \\
\text { Zero till drill } \\
\text { at } 30 \times 10 \mathrm{~cm} \\
\text { spacing }\end{array}$ & $\begin{array}{l}\text { Sowing with } \\
\text { seed drill at } \\
30 \times 10 \mathrm{~cm} \\
\text { spacing }\end{array}$ \\
\hline
\end{tabular}

Table 7. Treatment abbreviations and description of management protocols for different crops in Indian mustard-based cropping systems.

\section{Crop management}

Both dry as well as rainy season crops were optimally nourished with their respective recommended doses of macro and micro nutrients. The recommended dose of $\mathrm{N}, \mathrm{P}_{2} \mathrm{O}_{5}$ and $\mathrm{K}_{2} \mathrm{O}$ are 80 , 40 and $40 \mathrm{~kg} \mathrm{ha}^{-1}$ for Indian mustard; 120,80 and $50 \mathrm{~kg} \mathrm{ha}^{-1}$ for maize; 100, 80 and $50 \mathrm{~kg} \mathrm{ha}^{-1}$ for pearl millet; 20, 40 and $40 \mathrm{~kg} \mathrm{ha}^{-1}$ for green gram and cluster bean; and 30, 20 and $20 \mathrm{~kg} \mathrm{ha}^{-1}$ for sesame, respectively. Per hectare $40 \mathrm{~kg} \mathrm{~S}, 5 \mathrm{~kg} \mathrm{Zn}$ and $1 \mathrm{~kg} \mathrm{~B}$ to Indian mustard, and $5 \mathrm{~kg} \mathrm{Zn}$ to maize were also applied. An additional dose of $20 \mathrm{~kg} \mathrm{~N} \mathrm{ha}^{-1}$ was applied to PB and ZT treatments of Indian mustard to offset the effect of $\mathrm{N}$ immobilization. In rainy season, cluster bean, green gram and sesame was fertilized with full amount of $\mathrm{N}, \mathrm{P}_{2} \mathrm{O}_{5}$ and $\mathrm{K}_{2} \mathrm{O}$ at the time of sowing as basal application. Half dose of $\mathrm{N}$ and full dose of $\mathrm{P}_{2} \mathrm{O}_{5}$ and $\mathrm{K}_{2} \mathrm{O}$ as basal and remaining half $\mathrm{N}$ at the 30 days after sowing (DAS) was applied in pearl millet. Maize was fertilized with $1 / 3^{\text {rd }} \mathrm{N}$ and full dose of $\mathrm{P}_{2} \mathrm{O}_{5}$ and $\mathrm{K}_{2} \mathrm{O}$ and $\mathrm{ZnSo}_{4}$ at the time of seeding, while remaining $2 / 3^{\text {rd }} \mathrm{N}$ was top dressed in to equal splits at fifth leaf and tasseling stages. In the 
dry season, Indian mustard was fertilized with half dose of $\mathrm{N}$ and full dose of $\mathrm{P}_{2} \mathrm{O}_{5}, \mathrm{~K}_{2} \mathrm{O}, \mathrm{S}, \mathrm{ZnSo}_{4}$ and $\mathrm{B}$ at the time of sowing as basal application, and remaining half $\mathrm{N}$ was top dressed at the time of first irrigation. Glyphosate @ $1.0 \mathrm{~kg}$ a.i. ha ${ }^{-1}$ was sprayed 2-day prior to sowing in PB and ZT plots to control the weeds in both rainy and dry season. After sowing, atrazine @ $1.0 \mathrm{~kg}$ a.i. ha ${ }^{-1}$ as pre emergence (PE) in pearl millet and maize; pendimethalin @ $1.0 \mathrm{~kg}$ a.i. ha ${ }^{-1}$ as PE in Indian mustard, green gram and cluster bean; and alachlor @ $1.5 \mathrm{~kg}$ a.i. ha ${ }^{-1}$ as PE in sesame were applied in all plots (PB, ZT and CT). Additionally, one hand weeding was also done in CT plots for weed control at 30 DAS in all the crops.

The cluster bean, pearl millet, sesame and maize were harvested manually on maturity in the month of September. The green gram was harvested by hand picking of mature pods at three stages. All the rainy season crops were harvested by leaving $1 / 3^{\text {rd }}$ crop portion on soil surface as anchored residue in the PB and ZT plots and remaining were removed for cattle feed and fodder. CT plots were harvested 5 $\mathrm{cm}$ above the soil surface without leaving any residue. At $75 \%$ siliquae maturity, the mustard was harvested leaving $1 / 3^{\text {rd }}$ crop stubbles on soil surface as anchored residue in the PB and ZT plots and $5 \mathrm{~cm}$ above the soil surface without leaving any residue in the CT plots in the month of March. The equal number of rows was harvested from $14 \times 5.4 \mathrm{~m}$ net sown area of each crop and treatment in all the seasons and years.

\section{Recycling of crop residues}

In permanent beds and zero tilled plots the residue retained were $30,10,100,50,30$ and 20 per cent of mustard, cluster bean, green gram, maize, pearl millet and sesame, respectively. In cluster bean only $10 \%$ residue retained because of more pod bearing length of the stem, whereas, in green gram pods were handpicked and retained $100 \%$ residue. Management protocols related to residue management are given in Table 8 . In conventional tillage plots, $100 \%$ residue was removed. System wise residue retained $\left(\mathrm{Mg} \mathrm{ha}^{-1}\right)$ in $\mathrm{PB}+\mathrm{R}$ was $2.3,2.5,3.8,4.2,3.1$ and 2.7 , and in $\mathrm{ZT}+\mathrm{R}$ was $2.4,2.4,3.7,3.7,3.3,2.3$ from $\mathrm{F}-$ M, CB-M, GG-M, Mz-M, PM-M and S-M, respectively (Table 8).

\begin{tabular}{|l|c|c|c|c|c|c|}
\hline \multirow{2}{*}{$\begin{array}{l}\text { Cropping } \\
\text { system }\end{array}$} & \multicolumn{5}{|c|}{ Residue retained $\left(\mathrm{Mg} \mathrm{ha}^{-1}\right)$} \\
\cline { 2 - 7 } & Rainy crops & Mustard & System & Rainy crops & Mustard & System \\
\hline F-M & 0.0 & 2.3 & 2.3 & 0.0 & 2.4 & 2.4 \\
\hline CB-M & 0.2 & 2.3 & 2.5 & 0.2 & 2.2 & 2.4 \\
\hline GG-M & 1.6 & 2.2 & 3.8 & 1.3 & 2.4 & 3.7 \\
\hline Mz-M & 1.9 & 2.3 & 4.2 & 1.5 & 2.2 & 3.7 \\
\hline PM-M & 1.2 & 1.9 & 3.1 & 1.1 & 2.2 & 3.3 \\
\hline S-M & 0.4 & 2.3 & 2.7 & 0.3 & 2.0 & 2.3 \\
\hline
\end{tabular}

Table 8. Total residue load under different tillage and cropping system over the years.

\section{Yield of crops and system grain yield}

Equal number of rows of each crop were harvested manually from net plot area $(14 \times 5.4 \mathrm{~m})$ leaving anchored stubbles in the field as per treatment details (Table 8). The harvested produce was Sun dried and threshed using mechanical thresher (maize grains separated with the sheller). The stubbles left over in the field of each crop were measured using $1.0 \mathrm{~m}^{2}$ quadrant at three places from net plot and Sun dried. The stover yield was adjusted to the amount left in the field for total stover yield ha ${ }^{-1}$. The system productivity of different cropping systems was measured in to Indian mustard equivalent yield by converting yield of rainy season crops in to Indian mustard using equation with sesame as an example.

Indian mustard equivalent yield $\left(\mathrm{Mg} \mathrm{ha}^{-1}\right)=\frac{\text { Sesame yield }(\mathrm{Mg} \text { ha }-1) \mathrm{xMinimum} \text { support price of sesame }\left(\mathrm{US} \$ \mathrm{Mg}^{-1}\right)}{\text { Minimum support price of sesame }\left({\left.\mathrm{US} \$ \mathrm{Mg}^{-1}\right)}^{-1}\right)}$

\section{Net returns and relative economic efficiency}

The economic analysis/profitability was worked out for all the crops and cropping systems under the respective treatments. The total cost (TC) of cultivation includes all the input and related costs (field, 
labor, and electricity) that are involved in crop production from sowing to marketing. Gross returns (GR) were calculated by multiplying the crop yield with minimum support price that were offered by the Govt. of India, and the straw yield by current local market rates (Table 9). The net returns (NR) were calculated as the difference between the GR and the TC (NR = GR - TC). The system NRs were calculated by adding NRs of crops harvested within an individual calendar year. The price of inputs and outputs were given in the Table 9.

Relative economic efficiency (REE):

The comparative advantage through tillage alterations and cropping systems were represented through REE and expressed in percentage ${ }^{41}$.

$\mathrm{REE}=\frac{\Delta \mathrm{NR}}{\mathrm{A}} \times 100$

where, $\triangle \mathrm{NR}$ is the difference in the net returns from various tillage treatments over the control for main plots (CT) and the difference in net returns from various cropping systems over the fallow-mustard cropping system for subplots, A is the net returns from CT for main plots and the net returns from the fallow-mustard cropping system treatment for subplots.

Economic efficiency (EE):

The economic efficiency of various cropping systems under different tillage methods was calculated to determine per day return and calculated as:

$\mathrm{EE}=\frac{\mathrm{NR} \text { (US \$) }}{\mathrm{D}}$

where, NR is the net returns in US \$, and D is the duration of the crops in a system.

\begin{tabular}{|c|c|c|c|}
\hline \multirow[t]{2}{*}{ Item/Commodity } & \multicolumn{3}{|c|}{ Price input and output $\left(\$\right.$ unit $\left.^{-1}\right)$} \\
\hline & $2016-17$ & $2017-18$ & $2018-19$ \\
\hline Mustard grain $\left(\mathrm{kg}^{-1}\right)$ & 0.53 & 0.57 & 0.60 \\
\hline Mustard straw $\left(\mathrm{kg}^{-1}\right)$ & 0.01 & 0.01 & 0.01 \\
\hline Cluster bean grain $\left(\mathrm{kg}^{-1}\right)$ & 0.50 & 0.53 & 0.55 \\
\hline Cluster bean straw $\left(\mathrm{kg}^{-1}\right)$ & 0.07 & 0.07 & 0.07 \\
\hline Green gram grain $\left(\mathrm{kg}^{-1}\right)$ & 0.74 & 0.79 & 0.99 \\
\hline Maize grain $\left(\mathrm{kg}^{-1}\right)$ & 0.19 & 0.20 & 0.24 \\
\hline Maize straw $\left(\mathrm{kg}^{-1}\right)$ & 0.03 & 0.03 & 0.03 \\
\hline Pearl millet grain $\left(\mathrm{kg}^{-1}\right)$ & 0.19 & 0.20 & 0.28 \\
\hline Pearl millet straw $\left(\mathrm{kg}^{-1}\right)$ & 0.03 & 0.03 & 0.03 \\
\hline Sesame grain $\left(\mathrm{kg}^{-1}\right)$ & 0.71 & 0.75 & 0.89 \\
\hline Sesame straw $\left(\mathrm{kg}^{-1}\right)$ & 0.01 & 0.01 & 0.01 \\
\hline Urea $\left(50 \mathrm{~kg}^{-1}\right)$ & 4.19 & 3.80 & 3.80 \\
\hline Di-ammonium phosphate (DAP) $\left(50 \mathrm{~kg}^{-1}\right)$ & 18.34 & 18.34 & 17.77 \\
\hline Single super phosphate (SSP) $\left(50 \mathrm{~kg}^{-1}\right)$ & 4.55 & 4.55 & 5.12 \\
\hline Muriate of potash (MOP) $\left(50 \mathrm{~kg}^{-1}\right)$ & 10.31 & 10.31 & 12.72 \\
\hline Zinc sulphate $\left(\mathrm{ZnSo}_{4}\right)\left(5 \mathrm{~kg}^{-1}\right)$ & 4.69 & 4.98 & 6.97 \\
\hline Sulphur $(\mathrm{S})\left(5 \mathrm{~kg}^{-1}\right)$ & 3.16 & 3.16 & 3.16 \\
\hline Wage rate $\left(\right.$ person $^{-1}$ day $^{-1}$ ) & 4.38 & 4.56 & 4.93 \\
\hline US\$ conversion rate & \multicolumn{3}{|c|}{70.34} \\
\hline
\end{tabular}

Table 9. Cost of key inputs and outputs used for economic analysis during different years.

\section{Sustainability yield index (SYI)}

Minimum seed yield under each system when compared to the maximum observed yield of Indian mustard over the years can be quantified through the sustainability yield index (SYI). It is expressed as; 
SYI $=\frac{Y a-\sigma}{Y m}$

where, Ya is the mean yield, $\sigma$ is the standard deviation of the yield, and $\mathrm{Ym}$ is the maximum yield obtained under a set of management practices ${ }^{42}$.

\section{Production efficiency (PE)}

Production efficiency (PE) represents the increase in seed yield on a daily basis. It is the ratio of total yield obtained during the crop period and duration of the crop ${ }^{43}$. The higher production efficiency indicates a better translocation of photosynthates from the source to the sink. It can be calculated by the following mathematical equation:

$\mathrm{PE}=\frac{\mathrm{Ya}}{\Delta \mathrm{n}}$

where, $\mathrm{PE}$ is the production efficiency $\left(\mathrm{kg} \mathrm{ha}^{-1} \mathrm{day}^{-1}\right), \mathrm{Ya}$ is the total grain yield $\left(\mathrm{kg} \mathrm{ha}^{-1}\right)$, and $\Delta \mathrm{n}$ is the total duration of the study (270 days).

\section{Water productivity}

The amount of irrigation water applied to each plot was measured using a water meter. The total amount of water applied (input water) was computed by summing the irrigation (I) water and rainfall (R). The amount of irrigation water that was applied was quantified $\left(\mathrm{mm} \mathrm{ha}^{-1}\right)$ by using Eqs (1) and (2). The irrigation water use productivity (IWP) was calculated as:

$\mathrm{IWP}=\frac{\mathrm{SY}}{\mathrm{Wa}}$

Where, IWPis the irrigation water productivity in $\mathrm{kg}$ grain $\mathrm{M}^{-3}$ of water, $\mathrm{SY}$ is the seed yield $(\mathrm{kg})$ and Wa is the water applied through irrigation $\left(\mathrm{M}^{-3}\right)$.

\section{Partial factor productivity (PFP)}

It is a simple production efficiency expression, calculated in units of crop yield per unit of nutrient applied. It answers that how productive is a cropping system in comparison to its nutrient input.

$\mathrm{PFP}=\frac{\mathrm{Y}}{\mathrm{F}}$

Where, PFP is the partial factor productivity ( $\mathrm{kg}$ grain per $\mathrm{kg}$ nutrient applied), $\mathrm{Y}$ is the crop/system grain yield $\left(\mathrm{kg} \mathrm{ha}^{-1}\right)$ and $\mathrm{F}$ is the nutrient applied $\left(\mathrm{kg} \mathrm{ha}^{-1}\right)$.

\section{Statistical analysis}

The data were subjected to analysis of variance for critical differences using SSCNARS Portal online data analysis tool, IASRI (http://www.iasri.res.in/sscnars/2016). Treatment means were separated by Duncan Multiple Range Test at 5\% level of significance. The multiple least significant differences were worked out at $\mathrm{p}<0.05$ probability level from each data set. The least significant differences (LSD) and the coefficient of determination $\left(\mathrm{R}^{2}\right)$ were presented for respective parameters observed in the investigation.

\section{References:}

1. Friedrich, T., Derpsch, R. \& Kassam, A. Overview of the global spread of conservation agriculture. Field Actions Sci. Rep. Special Issue 6. (2012).

2. Hobbs, P.R. Conservation agriculture: what it is and why it is important for future sustainable food production? J. Agric. Sci. 145, 127-137 (2007).

3. Erenstein, O., Sayer, K., Wall, P., Dixon, J. \& Hellin, J. Adapting no-tillage agriculture to the smallholder maize and wheat farmers in the tropics and sub-tropics. In: Goddard, T., Zoebisch, M.A., Gan, Y.T., Ellis, W., Watson, A., Sombatpanit, S. (Eds.), No-till Farming Systems. Special Publication 3. World association of Soil and Water Conservation (WASWC), Bangkok, 253-277 (2008). 
4. Govaerts, B., Sayre, K.D., Goudeseune, B., De Corte, P., Lichter, K., Dendooven, L. \& Deckers, J. Conservation agriculture as a sustainable option for the central Mexican highlands. Soil Tillage Res. 103, 222-230 (2009).

5. Kassam, A., Friedrich, T., Shaxson, F. \& Pretty, J. The spread of conservation agriculture: justification, sustainability and uptake. Int. J. Agric. Sustain. 7, 292-320 (2009).

6. Thierfelder, C. \& Wall, P. Rotation in conservation agriculture systems of Zambia: effects on soil quality and water relations. Aust. J. Exp. Agric. 46, 1-17 (2010).

7. Das, T.K. et al. Conservation Agriculture in an irrigated cotton-wheat system of the western IndoGangetic Plains: crop and water productivity and economic profitability. Field Crops Res. 158, 24-33 (2014).

8. Parihar, C.M. et al. Energy auditing of long-term conservation agriculture based irrigated intensive maize systems in semi-arid tropics of India. Energy 142, 289-302. https://doi.org/10.1016/j.energy.2017.10.015. (2018).

9. FAO. Climate-Smart Agriculture: Sourcebook. Food and Agriculture Organization of the United nations. Retrieved from. http://www.fao.org/3/a-i3325e. (2013).

10. Kumar, V. et al. Can productivity and profitability be enhanced in intensively managed cereal systems while reducing the environmental footprint of production? Assessing sustainable intensification options in the breadbasket of India. Agric Ecosyst. Environ. 252, 132-147. http://dx.doi.org/10.1016/j.agee.2017.10.006 (2018).

11. Pittelkow, C.M. et al. Productivity limits and potentials of the principles of conservation agriculture. Nature 517, 365-368. (2015).

12. Giller, K. E., Witter, E., Corbeels, M. \& Tittonell, P. Conservation agriculture and smallholder farming in Africa: the heretics view. Field Crops Res. 114, 23-34. http://doi.org/doi:10.1016/j.fcr.2009.06.017.(2009).

13. Das, T.K. et al. Conservation Agriculture effects on crop and water productivity, profitability and soil organic carbon accumulation under a maize-wheat cropping system in the North-western Indo-Gangetic Plains. Field Crops Res. 215, 222-231. (2018).

14. Kassam, A., Friedrich, T. \& Derpsch, R. Global spread of conservation agriculture. Int. J. Environ. Stud. https://doi.org/10.1080/00207233.(2018).

15. Jat, R.S., Singh, V.V., Sharma, P. \& Rai, P.K. Oilseed brassica in India: Demand, supply, policy perspective and future potential. OCL 26, 8. https://doi.org/10.1051/ocl/2019005. (2019).

16. Kumar, A. Production barriers and technological options for sustainable production of rapeseedmustard in India. J. Oilseed Brassica 3(2), 67-77 (2012).

17. Simmons, B.L. \& Coleman, D.C. Microbial community response to transition from conventional to conservation tillage in cotton fields. Appl. Soil Ecol. 40, 518-528 (2008).

18. Helgason, B.L., Walley, F.L. \& Germida, J.J. Fungal and bacterial abundance in long-term no-till and intensive-till soils of the northern great plains. Soil Sci. Soc. Am. J. 73, 120-127 (2009).

19. Shekhawat, K., Rathore, S. S., Kandpal, B. K., Premi, O. P., Singh, D. \& Chauhan, B. S. Crop establishment techniques affect productivity, sustainability, and soil health under mustard-based cropping systems of Indian semi-arid regions. Soil Tillage Res. 158, 137-146. http://dx.doi.org/10.1016/j.still.2015.12.008 (2016).

20. Jat, H.S. et al. Effects of tillage, crop establishment and diversification on soil organic carbon, aggregation, aggregate associated carbon and productivity in cereal systems of semi-arid $\begin{array}{llllll}\text { Northwest India. } & \text { Soil } & \text { Tillage } & \text { Res. } & \text { 190, }\end{array}$ http://doi.org/doi:10.1016/j.still.2019.03.005(2019).

21. Gathala, M.K., Ladha, J.K., Saharawat, Y.S., Kumar, V., Kumar, V. \& Sharma, P.K. Effect of tillage and crop establishment methods on physical properties of a medium textured soil under a seven-year rice-wheat rotation. Soil Sci. Soc. Am. J. 75, 1851-1862 (2011).

22. Nandan, B., Sharma, B.C., \& Kumar, A. Mitigating Food Security Options through Climate Resilient Mustard-maize Based Intercropping Sequences for North-western-Himalayas. J. Food Secur. 1(2), 58-64 (2013). 
23. Oyeogbe, A., Ogunshakin, R., Vaghela, S. \& Patel, B. Towards Sustainable Intensification of Sesame-based Cropping Systems Diversification in Northwestern India. J. Food Secur. 3(1), 1-5 http://doi.org/doi:10.12691/jfs-3-1-1(2015).

24. Singh, A. \& Kharub, A.S. Performance of zero tillage in wheat- evidences from participatory research. Fertil. Market News. 32(11), 1-5 (2001).

25. Jat, H.S. et al. Conservation Agriculture-based Sustainable Intensification of Cereal Systems Leads to Energy Conservation, Higher Productivity and Farm Profitability. Environ. Manage. https://doi.org/10.1007/s00267-020-01273-w (2020).

26. Jakhar, P. et al. Resource conservation practices in maize-mustard cropping system: Impact on energy, soil carbon and nutrient dynamics. J. Environ. Biol.39, 440-446. http://doi.org/10.22438/jeb/39/4/MRN-549. (2018).

27. Das, T.K. et al. Conservation Agriculture in rice-mustard cropping system for five years: Impacts on crop productivity, profitability, water-use efficiency, and soil properties. Field Crops Res.250, 107781. https://doi.org/10.1016/j.fcr.2020.107781. (2020).

28. Pradhan, A., Chan, C., Roul, P. K., Halbrendt, J. \& Sipes, B. Potential of conservation agriculture (CA) for climate change adaptation and food security under rainfed uplands of India: A transdisciplinary approach. Agric. Syst. 163, 27-35. http://dx.doi.org/10.1016/j.agsy.2017.01.002. (2018).

29. Choudhary, R.L. \& Behera, U.K. Conservation agricultural and nitrogen management practices in maize-wheat cropping system: Effect on productivity, nutrient uptake and profitability of maize. $\begin{array}{lllll}\text { Indian } & J & \text { Soil } & \text { Cons. }\end{array}$ https://www.indianjournals.com/ijor.aspx?target=ijor:ijsc \&volume $=47 \&$ issue $=3 \&$ article $=011$ (2019).

30. Susha, V.S., Das, T.K., Nath, C.P., Pandey, R., Paul, S. \& Ghosh, S. Impacts of tillage and herbicide mixture on weeds interference, agronomic productivity and profitability of a maizewheat system in the North-western Indo-Gangetic Plains. Field Crops Res. 219, 180-191. (2018).

31. Behera, B., Das, T.K. \& Rathi, N. Carry-over effect of brown manuring supplemented with nitrogen on productivity and profitability in succeeding wheat (Triticum aestivum). Indian J. Agric. Sci. 89, 708-713. (2019).

32. Hao, X.H., Liu, S.L., Wu, J.S., Hu, R.G., Tong, C.L. \& Su, Y.Y. Effect of long-term application of inorganic fertilizer and organic amendments on soil organic matter and microbial biomass in three subtropical paddy soils. Nutr. Cycl. Agroecosyst. 81, 17-24. (2008).

33. Choudhary, R.L. \& Behera, U.K. Effect of conservation agricultural and nitrogen management practices on root architecture and soil properties in maize-wheat cropping system. J. Soil Water Conserv. 19(3), 261-270. https://doi.org/10.5958/2455-7145.2020.00035.1 (2020).

34. Kumar, N. et al. Impact of zero-till residue management and crop diversification with legumes on soil aggregation and carbon sequestration. Soil Tillage Res. 189, 158-167. (2019).

35. Nath, C.P. et al. Weeds and nitrogen management effects on weeds infestation and crop productivity of wheat-mungbean sequence in conventional and conservation tillage practices. Agric. Res. 6, 33-46 (2017).

36. Devine, S., Markewitz, D., Hendrix, P. \& Coleman, D. Soil aggregates and associated organic matter under conventional tillage, no-tillage, and forest succession after three decades. PLoS One 9 (1), e84988. (2014).

37. Bhattacharyya, R., Das, T.K., Pramanik, P., Ganeshan, V., Saad, A.A. \& Sharma, A.R. Conservation agriculture effects on soil organic carbon accumulation and crop productivity under a rice-wheat cropping system in the western Indo-Gangetic Plains. Eur. J. Agron. 70, 11-21. (2015).

38. Singh, V.K. et al. Soil physical properties, yield trends and economics after five years of conservation agriculture based rice-maize system in north-western India. Soil Tillage Res.155, 133-148. (2016). 
39. Sarker, J.R. et al. Carbon and nutrient mineralization dynamics in aggregate-size classes from different tillage systems after input of canola and wheat residues. Soil Biol. Biochem. 116, 22-38. http://dx.doi.org/10.1016/j.soilbio.2017.09.030 (2018).

40. Aziz, I., Mahmood, T. \& Islam, K.R. Effect of long term no-till and conventional tillage practices on soil quality. Soil Tillage Res. 131, 28-35 (2013).

41. Parasd, D., Urkurkar, J.S., Bhoi, S.K. \& Nag, N. Potential and economic analysis of different rice based cropping systems in Chhattisgarh plains. Res J Agric Sci. 2, 36-39 (2011).

42. Singh, R.P., Das, S.K., Rao, U.M.B. \& Reddy, M.N. Towards sustainable dry land agricultural practices. Central Research Institute for Dry Land Agriculture, Hyderabad. 5-9. (1990).

43. Rautaray, S.K., Dash, P.C. \& Sinhabalu, D.P. Increasing farm income through rice (Oryza sativa)-fish based integrated farming system in rainfed lowlands of Assam. Indian J. Agric. Sci. 75(2), 79-82 (2005).

\section{Acknowledgements}

The author is thankfully acknowledge the Director, ICAR-DRMR, Bharatpur and ICAR, New Delhi for providing basic infrastructure facility and financial support in executing the field and laboratory works during the experimentation.

\section{Author contributions}

R.S. participated in conducting the research, data analysis, and writing of the manuscript; R.L., H.V. and M.K. participated in the laboratory analysis and writing of the manuscript; V.V. and P.K. participated in research design and editing of manuscript.

\section{Competing interests}

The authors declare no competing interests.

\section{Figure captions}

Fig.1. Yield of rainy season crops in Indian mustard-based cropping systems under different CA practices (mean of 3 yrs).

Fig. 2. Net return of different CA-based Indian mustard systems (3-year mean).

Fig. 3. Sustainable yield index of different CA-based Indian mustard-based systems (3-year mean).

Fig. 4. Production efficiency of CA-based Indian mustard systems (3-year mean).

Fig. 5. Economic efficiency of CA-based Indian mustard systems (3-year mean).

Fig. 6. Irrigation water productivity of CA-based Indian mustard systems (3-year mean).

Fig.7. Monthly maximum and minimum temperature, and rainfall during the crop growing seasons (201617, 2017-18 and 2018-19). Source: Agromet Observatory, ICAR-DRMR, Bharatpur, Rajasthan (India). 
Figures

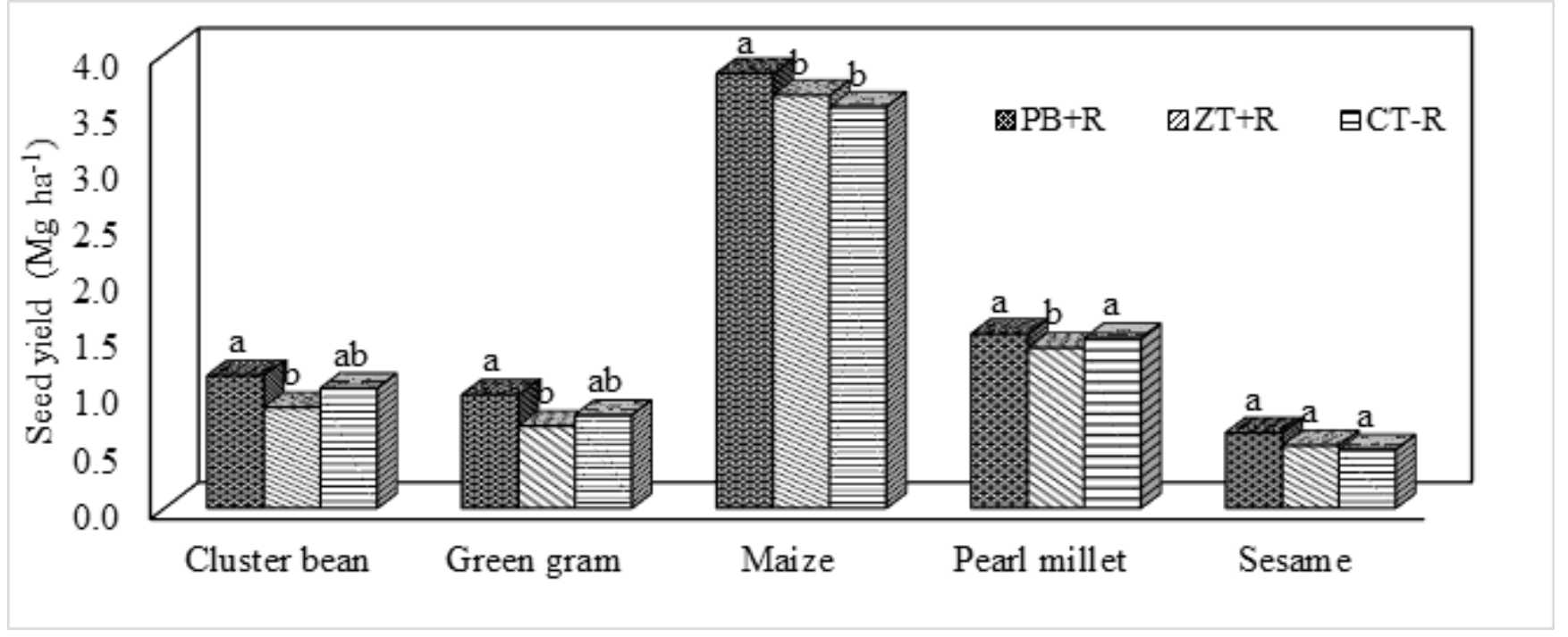

Figure 1

Yield of rainy season crops in Indian mustard-based cropping systems under different CA practices (mean of $3 \mathrm{yrs}$ ).

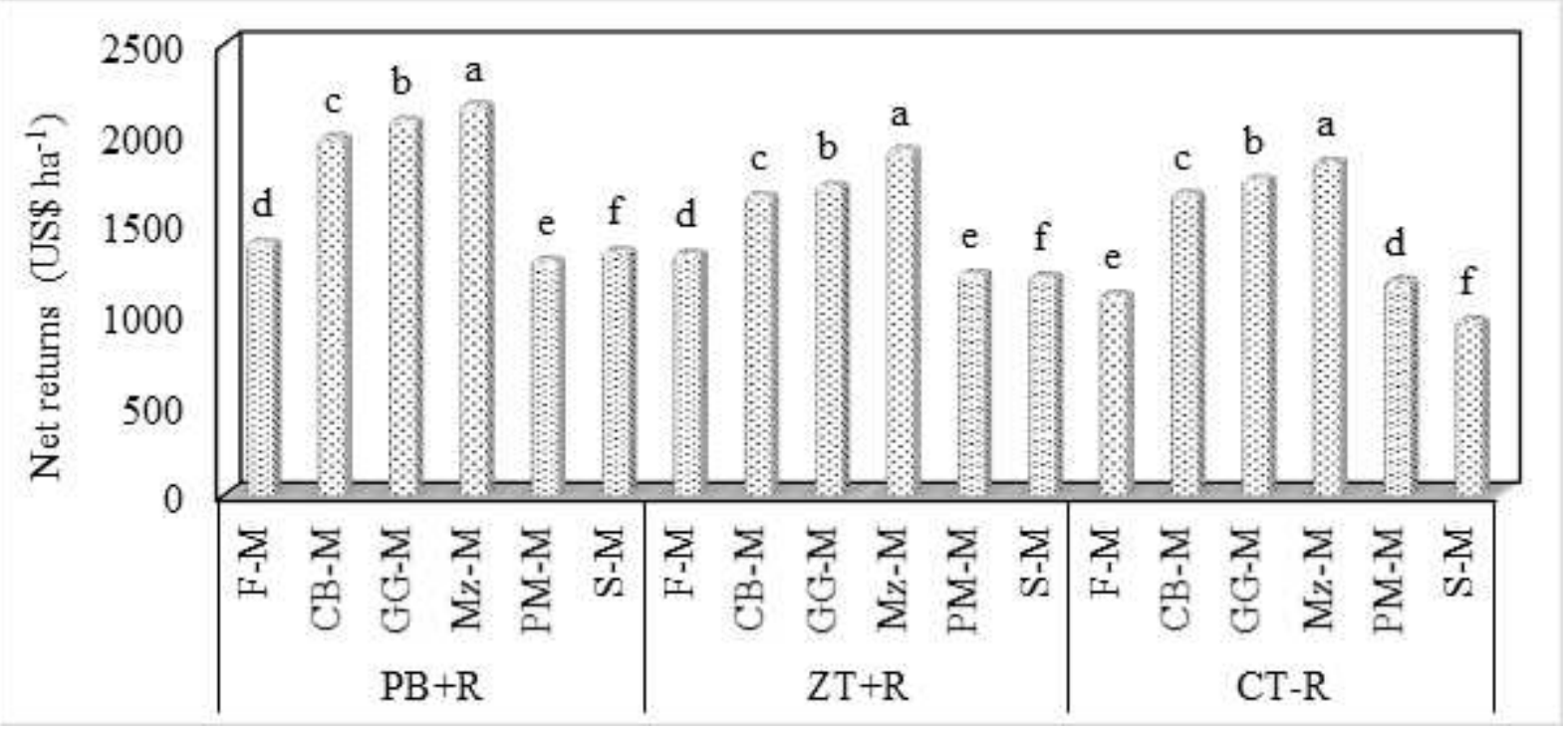

Figure 2

Net return of different CA-based Indian mustard systems (3-year mean). 


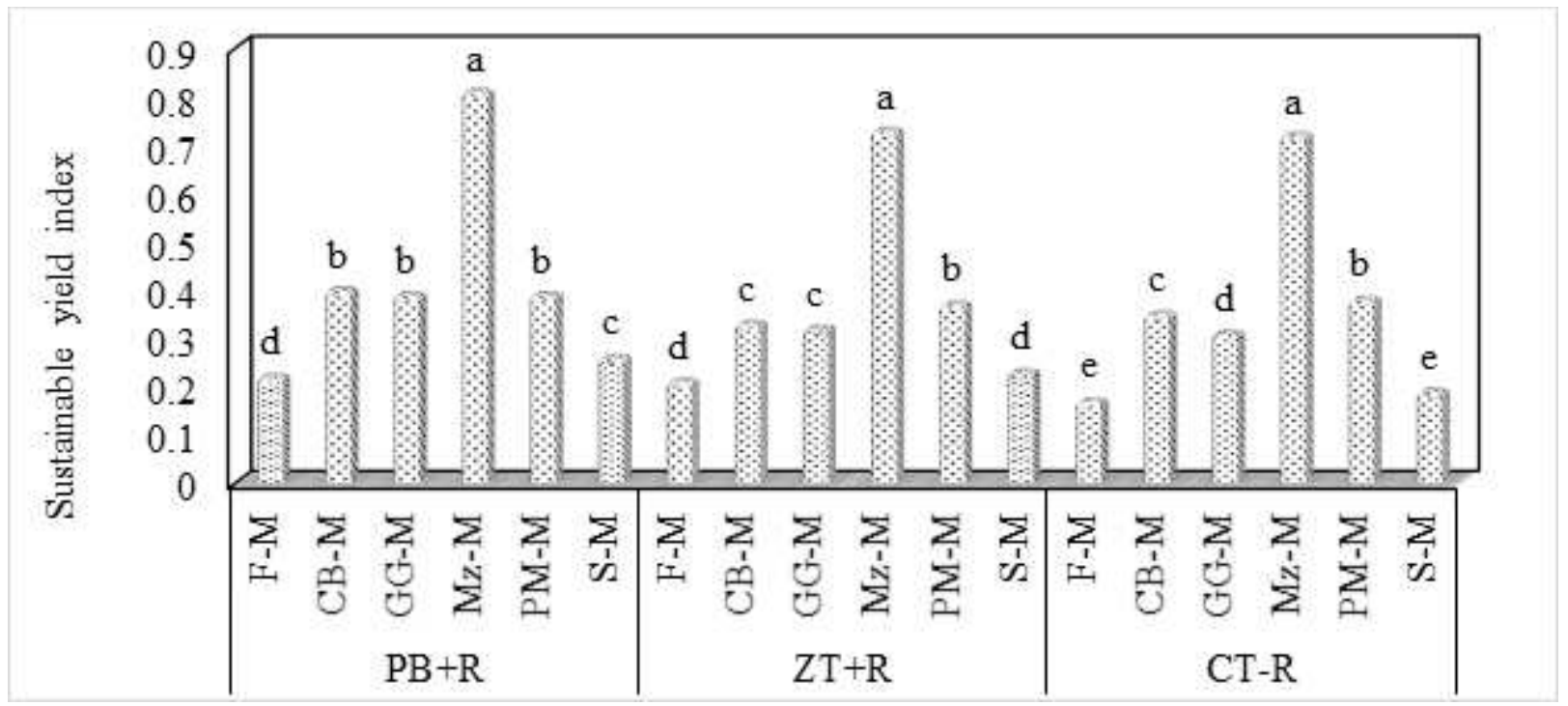

Figure 3

Sustainable yield index of different CA-based Indian mustard-based systems (3-year mean).

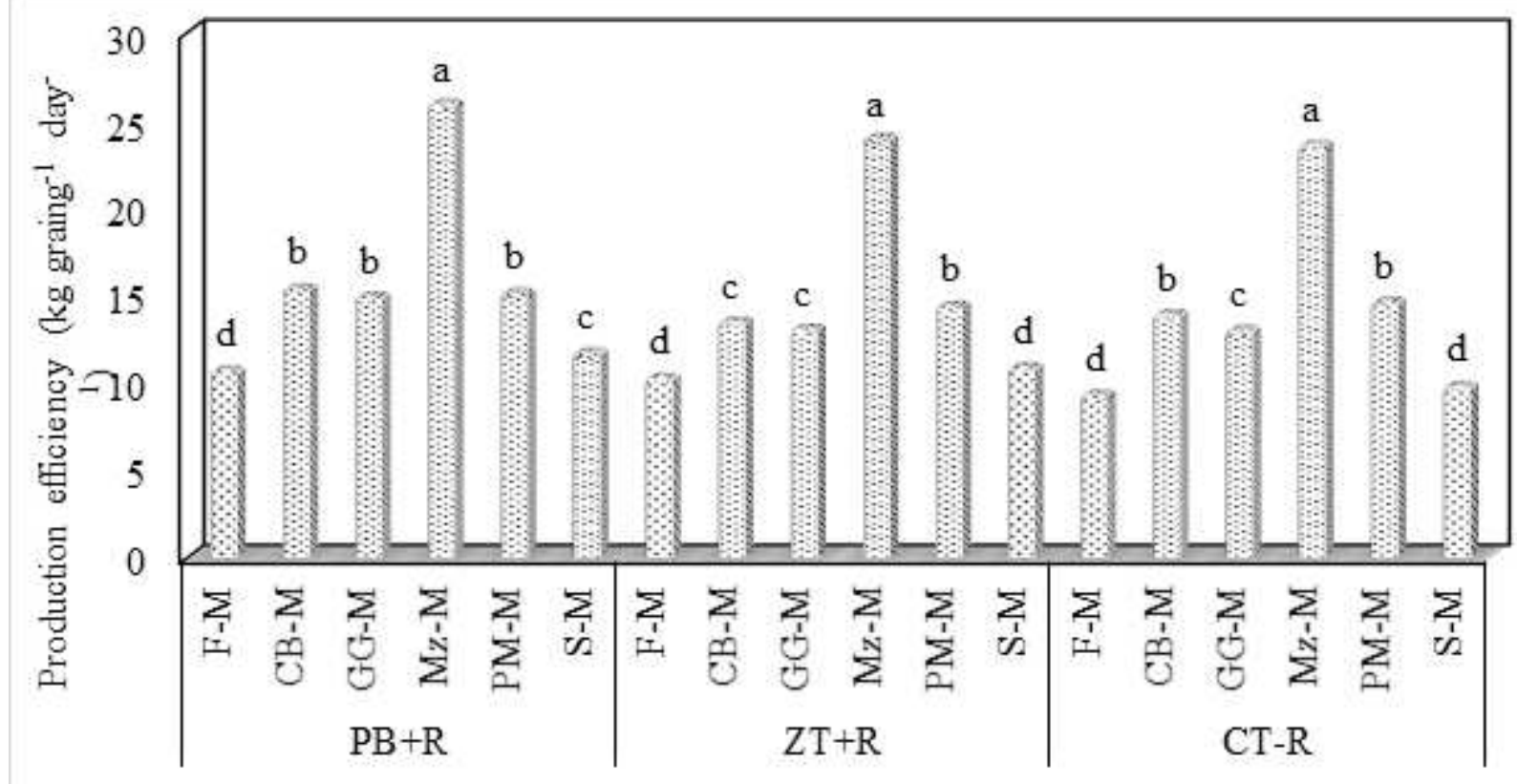

Figure 4

Production efficiency of CA-based Indian mustard systems (3-year mean). 


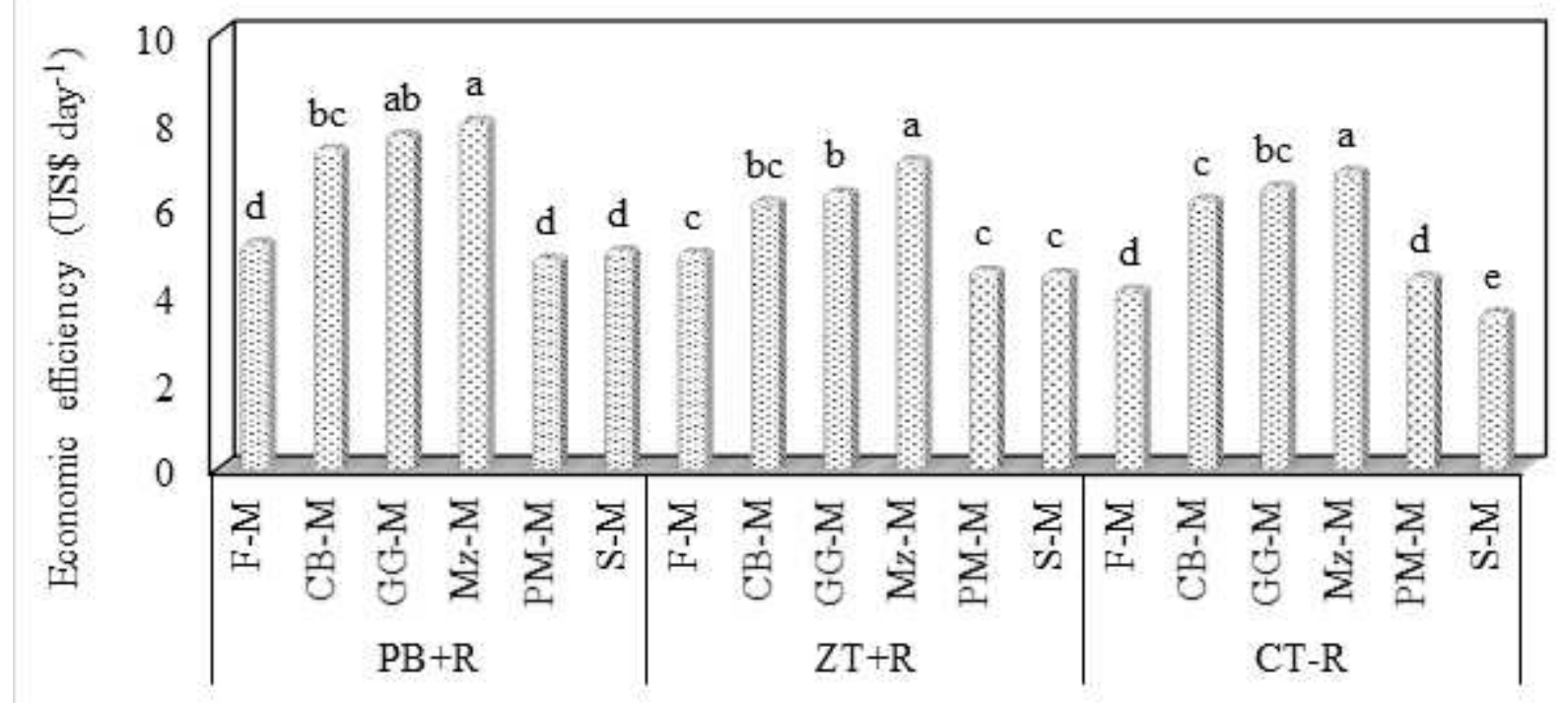

Figure 5

Economic efficiency of CA-based Indian mustard systems (3-year mean).

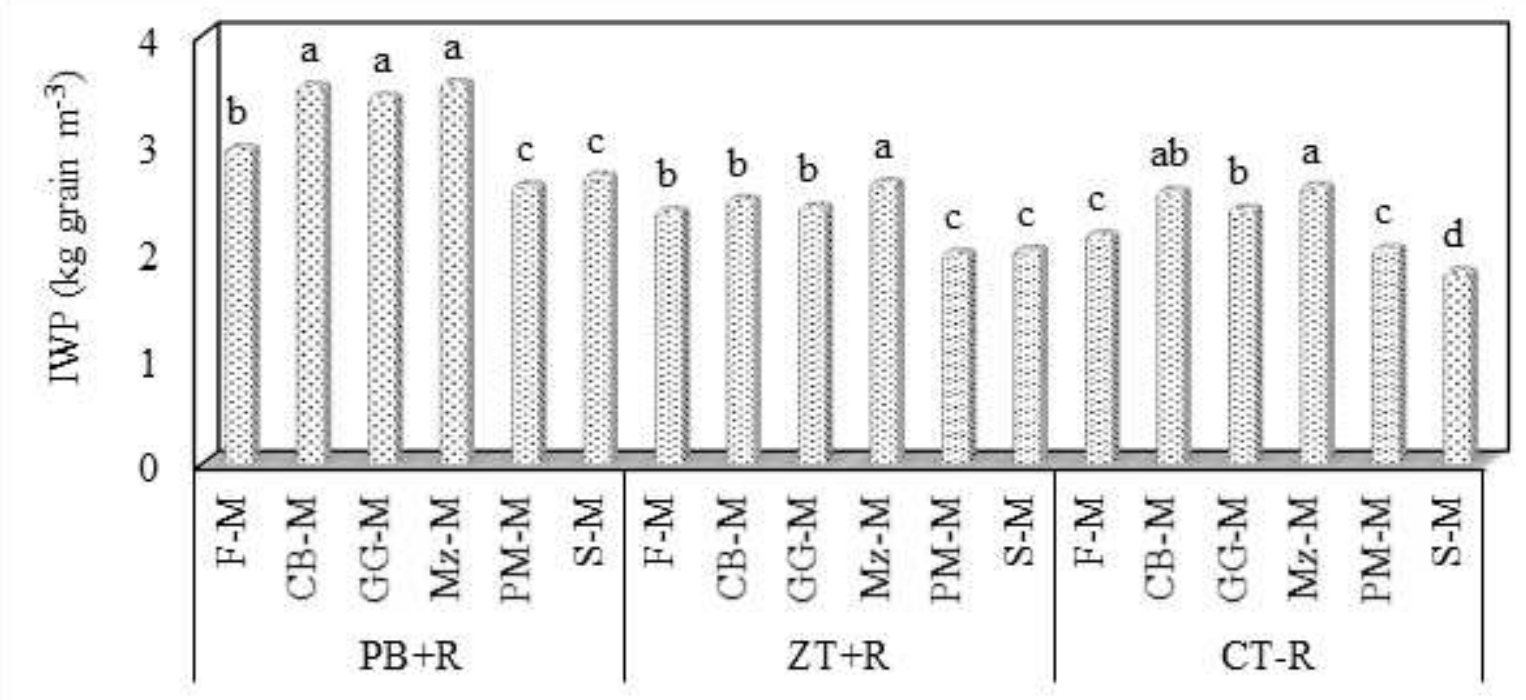

Figure 6

Irrigation water productivity of CA-based Indian mustard systems (3-year mean). 


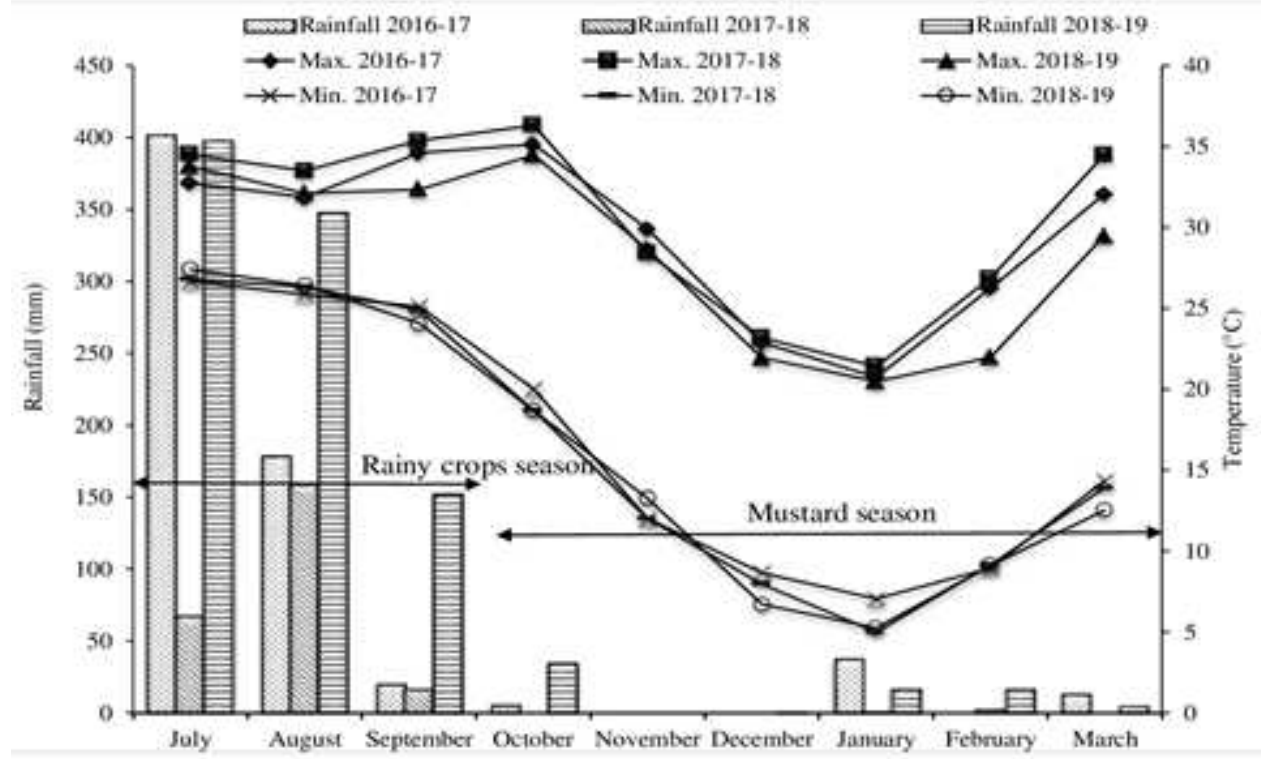

Figure 7

Monthly maximum and minimum temperature, and rainfall during the crop growing seasons (2016-17, 2017-18 and 2018-19). Source: Agromet Observatory, ICAR-DRMR, Bharatpur, Rajasthan (India). 